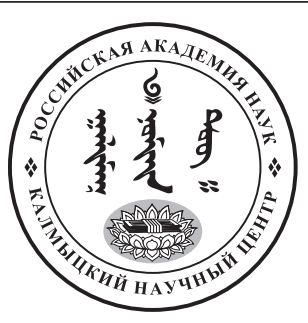

Published in the Russian Federation

Oriental Studies (Previous Name: Bulletin of the Kalmyk Institute

for Humanities of the Russian Academy of Sciences)

Has been issued as a journal since 2008

ISSN: 2619-0990; E-ISSN: 2619-1008

Vol. 14, Is. 5, pp. 981-1005, 2021

Journal homepage: https://kigiran.elpub.ru

УДК / UDC 902

DOI: 10.22162/2619-0990-2021-57-5-981-1005

\title{
Динамика хозяйственного освоения Посурья в I тысячелетии н.э. Часть 1: данные стратиграфического анализа пойменных и балочных отложений
}

Леонид Александрович Вязов ${ }^{1}$ Елена Викторовна Пономаренко ${ }^{2}$ Екатерина Георгиевна Ершова ${ }^{3}$, Юлия Анатольевна Салова ${ }^{4}$, Николай Станиславович Мясников 5

${ }^{1}$ Институт проблем освоения Севера Тюменского научного центра СО РАН (д. 86, ул. Малыгина, 625026 Тюмень, Российская Федерация)

кандидат исторических наук, ведущий научный сотрудник

iD 0000-0002-2074-9276. E-mail: 1.a.vyazov@gmail.com

2 Университет Оттавы (д. 60, Университет, K1N 6N5 3 Оттава, Канада) кандидат биологических наук, профессор

iD 0000-0003-3718-7801. E-mail: eponoma3@uOttawa.ca

${ }^{3}$ Московский государственный университет (1, ул. Колмогорова, 119991 Москва, Российская Федерация)

кандидат биологических наук, доцент

iD 0000-0002-5421-9572. E-mail: ekaterinagershova@mail.ru

${ }^{4}$ Институт проблем освоения Севера Тюменского научного центра СО РАН (д. 86, ул. Малыгина, 625026 Тюмень, Российская Федерация)

научный сотрудник

iD 0000-0002-8076-6887. E-mail: yadviga13ya@gmail.com

5 Чувашский государственный институт гуманитарных наук (д. 29, корп. 1, Московский пр., 428015 Чебоксары, Российская Федерация)

кандидат исторических наук, старший научный сотрудник

(iD)0000-0002-4557-8995. E-mail: myasnikovn1988@gmail.com

(C) КалмНЦ РАН, 2021

(С) Вязов Л. А., Пономаренко Е. В., Ершова Е. Г., Салова Ю. А., Мясников Н. С., 2021.

Аннотация. В статье приводятся результаты комплексного ландшафтно-археологического исследования динамики взаимодействия человека и окружающей среды на территории Среднего Посурья в I тыс. н. э. Проанализированные данные были получены в ходе изучения поймы 
p. Сура в нижнем течении р. Малая Сарка. Анализ пойменных отложений и погребенных почв показал, что в течение I тыс. до н. э. - I тыс. н. э. сменилось несколько природно-климатических циклов, в течение которых пойма периодически становилась доступной для различных видов хозяйственного освоения. К раннему железному веку (I тыс. до н. э. - II-III вв. н. э.) относится формирование на исследованном участке поймы р. Суры серых лесных почв. В этот период пойма оставалась незаселенной, а население осваивало участки высоких террас и коренных берегов рек. Напротив, во второй четверти I тыс. н. э. наиболее благоприятные условия для заселения сложились именно на пойменных участках, покрытых широколиственным лесом. Освоение пойменных ландшафтов Посурья в это время осуществлялось носителями средневолжского варианта киевской культуры, в результате хозяйственной активности которого происходит постепенное сведение лесов и залужение поверхности. Во второй половине V в. происходит резкая интенсификация паводков и увеличение стока. Памятники этого времени относятся к развитому этапу именьковской культуры; они расположены на верхних террасах. Новый этап низкой поемности относится к средневековому времени (VIII-XIII вв.), почвы этого времени несут следы остепнения и последующей распашки пойменных ландшафтов. Позднее, в эпоху позднего средневековья и начала Нового времени, распашка смещается на водоразделы и интенсифицируется, а в поймах вновь начинается накопление слоистых аллювиальных отложений, маркирующих частые и интенсивные паводки. Прослеженная динамика обводненности сурской поймы асинхронна данным, полученным по другим исследованным регионам Русской равнины, что ставит вопрос о наличии связи между доступностью пойм для хозяйственного освоения и миграционными процессами.

Ключевые слова: Среднее Посурье, ландшафтная археология, археология пойм, педолитогенные комплексы, ранний железный век, Великое переселение народов, динамика взаимодействия человека и окружающей среды

Благодарность. Исследование выполнено в рамках гранта РФФИ «Исследования археологических памятников Среднего Посурья периода римских влияний и Великого переселения народов» (№ 17-31-01065).

Для цитирования: Вязов Л. А., Пономаренко Е. В., Ершова Е. Г., Салова Ю. А., Мясников Н. С. Динамика хозяйственного освоения Посурья в I тысячелетии н.э. Часть 1: данные стратиграфического анализа пойменных и балочных отложений // Oriental Studies. 2021. T. 14 (5). C. 981-1005. DOI: 10.22162/2619-0990-2021-57-5-981-1005

\title{
Dynamics of Economic Development in the Sura River Valley, $1^{\text {st }}$ Millennium CE. Part 1: Stratigraphic Analysis of Floodplain and Gully Sediments
}

\author{
Leonid A. Vyazov ${ }^{1}$,Elena V. Ponomarenko ${ }^{2}$,Ekaterina G. Ershova ${ }^{3}$, Yulia A. Salova ${ }^{4}$, \\ Nikolay S. Myasnikov ${ }^{5}$
}

${ }^{1}$ Institute of the Problems of Northern Development, Tyumen Scientific Centre, Siberian Branch of the RAS (86, Malygin St., 625026 Tyumen, Russian Federation)

Cand. Sc. (History), Leading Research Associate

iD 0000-0002-2074-9276. E-mail:1.a.vyazov@gmail.com

${ }^{2}$ University of Ottawa (60, University, K1N 6 N5 3 Ottawa ON, Canada)

Cand. Sc. (Biology), Adjunct Professor

iD 0000-0003-3718-7801. E-mail: eponoma3@uOttawa.ca

${ }^{3}$ Lomonosov Moscow State University (1, Kolmogorov St., 119991 Moscow, Russian Federation)

Cand. Sc. (Biology), Associate Professor

iD 0000-0002-5421-9572. E-mail: ekaterinagershova@mail.ru

${ }^{4}$ Institute of the Problems of Northern Development, Tyumen Scientific Centre, Siberian Branch of the RAS (86, Malygin St., 625026 Tyumen, Russian Federation) 
Research Associate

iD 0000-0002-8076-6887. E-mail: yadviga13ya@gmail.com

${ }^{5}$ Chuvash State Institute for the Humanities (29/1, Moskovsky Ave., 428015 Cheboksary, Russian Federation)

Cand. Sc. (History), Senior Research Associate

iD 0000-0002-4557-8995. E-mail: myasnikovn1988@gmail.com

\author{
(C) KalmSC RAS, 2021 \\ (C) Vyazov L. A., Ponomarenko E. V., Ershova E. G., Salova Yu. A., Myasnikov N. S., 2021
}

\begin{abstract}
The article summarizes the results of a comprehensive landscape-archaeological study of the dynamics of human-environmental interaction in the Middle Sura region during the first millennium AD. The data resulted from the study of the River Sura floodplain at the former confluence of the Sura and the Malaya Sarka. The analysis of the sediments and buried soils indicates that the period between the first millennium $\mathrm{BC}$ and the first millennium AD saw a series of climatic cycles changing each other, with the floodplain periodically being available for various types of economic development. The Early Iron Age (first millennium $\mathrm{BC}-2^{\text {nd }}-3^{\text {rd }}$ centuries AD) saw the formation of grey forest soils in the part of the floodplain under study. During this period, the area remained uninhabited, while the population was involved in the development of the elevated terraces and riverbanks. In contrast, in the second quarter of the first millennium AD the floodplain covered at the time by broadleaf forest had the most favorable conditions for settlement; the area was developed by the population that belonged to the Middle Volga variant of the Kiev culture. Their economic activity resulted in the gradual deforestation of the floodplain, with meadow landscapes arising instead of the forest. The second half of the $5^{\text {th }}$ century saw drastic intensification of the floods and an increased runoff. The sites assigned to this period represent the developed stage of the Imen'kovo culture; these were located on the elevated terraces. The new stage of low flooding dates to the medieval period $\left(8^{\text {th }}-13^{\text {th }}\right.$ centuries), the soils bearing traces of steppe formation and subsequent development of the floodplain. Later, in the late Middle Age and the early Modern period, tillage shifted to watersheds and intensified, while the accumulation of layered alluvial deposits on the floodplain started again, with frequent and intense floods taking place. The study of the dynamics of the moistening of the Sura floodplain is asynchronous with the data of other studied regions of the Russian Plain, which raises the question of a relationship between the availability of floodplains for economic development and migration processes.
\end{abstract}

Keywords: Middle Sura region, landscape archaeology, archaeology of floodplains, pedolithogenic complexes, the Early Iron Age, the Migration period, dynamics of human-environmental interaction Acknowledgments. The reported study was funded by RFBR, project no. 17-31-01065 'Exploring Archaeological Sites of the Middle Sura Region from the Roman and Migration Periods'.

For citation: Vyazov L. A., Ponomarenko E. V., Ershova E. G., Salova Yu. A., Myasnikov N. S. Dynamics of Economic Development in the Sura River Valley, $1^{\text {st }}$ Millennium CE. Part 1: Stratigraphic Analysis of Floodplain and Gully Sediments. Oriental Studies. 2021. Vol. 14 (5): 981-1005. (In Russ.). DOI: 10.22162/2619-0990-2021-57-5-981-1005

\title{
है
}

\section{Введение}

До начала II тыс. н. э. подавляющее большинство археологических памятников в Среднем Поволжье располагалось на берегах рек, а многие - непосредственно в пойме [Vyazov et al. 2019]. Реки были неотъемлемой частью хозяйственной организации территории, поэтому следы присутствия человеческих коллективов должны быть наиболее заметными именно в этих элементах ландшафта. В автоморфных местообитаниях следы разных стадий заселения могут быть спрессованы, перекрываясь в одном и том же слое почвы, в то время как в поймах даже очень близкие по возрасту события часто разделяются аллювиальными наносами.

В последнее десятилетие появились работы, демонстрирующие перспективность палеоботанического анализа (в частности, 
анализа макроостатков и пыльцы) овражно-балочных наносов для обнаружения следов обитания древних коллективов и реконструкции характера природопользования (например: [Scherer et al. 2021; Ponomarenko et al. 2020; Пономаренко и др. 2015; Kaal et al. 2011]). Несмотря на растущий интерес к археологии поймы [Кренке 2019], работы по реконструкции динамики хозяйственного освоения на основании сопряженного анализа стратиграфии и почвенных макроостатков в пойменных отложениях Русской равнины до сих пор немногочисленны [Alexandrovski et al. 2018].

Что же касается Среднего Поволжья, то такие исследования и вовсе единичны. Так, на территории региона были описаны три погребенные почвы, маркирующие региональные перерывы в осадконакоплении (периоды низкой поемности). Их возраст составляет около 6800-5000, 3800-3000 и 2400-1200 л. н. [Мозжерин, Курбанова 2004; Галимова и др. 2016; Курбанова 1991]. Слабая изученность погребенных пойменных почв средневолжского региона в значительной степени обусловлена затоплением при создании водохранилищ части долины Волги и приустьевых участков ее притоков, т. е. наиболее освоенных в древности территорий. В этой ситуации важнейшими для изучения микрорегионами становятся срединные участки течения средних и малых рек. Одним из таковых выступает среднее течение р. Суры, где на протяжении 60 км от с. Сурское до г. Алатыря разведочным обследованием авторов выявлено два десятка местонахождений погребенных почв разного возраста. Часть из них ассоциирована с археологическими памятниками, что предполагает включение незатопляемых участков пойм в зоны хозяйственного освоения древним населением и делает погребенные почвы важным источником для реконструкции изменений климата, а также связанных с ними систем расселения и динамики землепользования на территории Среднего Поволжья.

Целью настоящей работы является применение детального палеоботанического анализа стратифицированных пойменных и балочных отложений для понимания динамики взаимодействия человека и окружающей среды в Среднем Посурье. Исследования проводились в рамках программы работ международной рабочей группы по изучению проблем ландшафтной археологии лесостепной зоны в голоцене [Ситдиков и др. 2016] и включали в себя два этапа: (1) стратиграфический анализ обнажений и разрезов с целью выделения слоев для опробования и их предварительной корреляции; и (2) палинологический анализ и анализ состава крупных фракций выделенных стратиграфических единиц.

В настоящей статье приводятся результаты стратиграфического анализа вскрытых отложений; данные анализа почвенных макроостатков, палинологического анализа, а также общие выводы относительно реконструкции динамики хозяйственного освоения микрорегиона будут приведены во второй части исследования, которая будет опубликована в одном из следующих номеров журнала.

\section{Общая характеристика района работ и расположенных в нем археологических памятников}

Территория Среднего Посурья охватывает пограничные участки Чувашской Республики, Республики Мордовия и Ульяновской области, на границе современных зон широколиственных лесов и лесостепи. Этот регион, как минимум с эпохи неолита, являлся контактной зоной различных групп населения. В раннем железном веке здесь проходила юго-западная граница распространения культур ананьинской области. Позднее, в первые века н. э., Среднее Посурье становится южным пределом распространения раннего этапа древностей типа Сендимиркино-Таутово, относимых исследователями к раннему этапу развития древнемордовской культуры. Во второй четверти I тыс. н. э. области в среднем течении р. Суры вошли в ареал формирования средневолжского варианта киевской и именьковской культур, став на несколько столетий фронтиром древнемордовского и именьковского населения. Позднее, в эпоху средневековья, этот регион становится западным пределом Волжской Булгарии, а в золотоордынский период здесь формируется восточный форпост древнерусского Нижегородского княжества [Вязов и др. 2020: 354-356 1 ].

${ }^{1}$ Там же см. обзор истории изучения региона. 
Неоднократная и последовательная смена населения на территории Среднего Посурья сопровождалась изменением стратегий хозяйственного освоения региона, что проявилось в изменении систем расселения, топографии памятников и технологий ведения хозяйства. Поэтому изучение динамики взаимодействия человека и окружающей среды на материалах памятников региона стало одной из важнейших задач международной археологической экспедиции по изучению историко-культурной динамики в Посурье в I тыс. н. э. в 2015-2019 гг. Наиболее значимые результаты в области решения указанных проблем были получены в результате ландшафтно-археологических исследований в окрестностях с. Иваньково-Ленино [Вязов и др. 2020].

Здесь, на участке долины р. Суры протяженностью около 10 км между селами Иваньково-Ленино и Сара, в 2015-2019 гг. экспедицией была исследована группа памятников раннего железного века, эпохи Великого переселения народов и средневекового времени, большая часть которых была обнаружена краеведом А. А. Макеевым в 1970-е гг. (рис. 1).

С геоморфологической точки зрения, Иваньковский микрорегион представляет собой участок асимметричной долины p. Суры, с высоким (до 80 м над рекой) левым берегом, сложенным коренными породами, и низким правым, представленным поймой и комплексом разновозрастных терpac. В центральной части участка исследования расположена долина р. Малая Сарка. Современное русло реки было искусственно проложено в XIX в.; древнее русло реконструируется по данным спутниковой и аэрофотосъемки (рис. 2).

Ранний железный век на территории Иваньковского микрорегиона представлен единичной находкой бронзовой кольцевой бляхи с орнитоморфным украшением, сделанной на территории Макеевского селища на правом берегу реки, относящаяся, по-видимому, к ананьинскому времени [Мясников 2014: 279].

К концу раннего железного века и началу эпохи Великого переселения народов (II-III вв. н. э.) относится городище Иваньковская Стрелка, с которого происходят находки сендимиркинско-таутовского круга - раннего этапа древнемордовской куль- туры. Находки того же культурного круга происходят из подъемного материала с территории селища Capa-1 и 2.

Эпоха Великого переселения представлена памятниками двух культурных групп. Материалы, относящиеся к средневолжскому варианту киевской культуры (близкие памятникам типа Сиделькино-Тимяшево, выделенным Д. А. Сташенковым [Сташенков 2005; Вязов, Сташенков 2013: 51]), выявлены на Макеевском селище в пойме правого берега р. Суры; к этому же культурному кругу относятся расположенные на краю первой надпойменной террасы селища Capa-1 и 2, одно из них (Cара-1) исследовалось раскопками в течение двух полевых сезонов [Вязов и др. 2020: 359-361]. На основании полученных радиоуглеродных дат памятники средневолжского варианта киевской культуры в Посурье относятся ко второй половине III-IV вв. н. э.

К более позднему времени относятся памятники развитого этапа именьковской культуры (V-VI вв. н. э.) - городища Иваньково-Ленинское Шолм и Сарское Ладыюжья Гора [Вязов и др. 2016: 60-70; 8082], а также прилегающие к городищам селища. Именьковские памятники занимают высокое положение в рельефе, они расположены на краю коренного берега р. Суры, городища - на мысах между отрогами оврагов.

Еще два памятника - расположенные на краю первой надпойменной террасы селища Сара-3 и 4 - известны только по материалам поверхностных сборов, на основании которых они могут быть широко датированы 2-3 четвертью I тыс. н. э., данных для уточнения культурной принадлежности недостаточно.

Наконец, к позднему средневековью (XIV в. и позднее) относятся памятники на территории с. Сара, отражающие освоение края населением нижегородского княжества [Вязов и др. 2020: 361-362].

Таким образом, по археологическим данным, фиксируются несколько этапов освоения исследуемого микрорегиона:

1) во 2-3 четверти I тыс. до н. э. - населением культур ананьинской области;

2) во II-ІІІ вв. н. э. - носителями древностей типа Сендимиркино-Таутово;

3) в III-IV вв. н. э. - населением средневолжского варианта киевской культуры; 


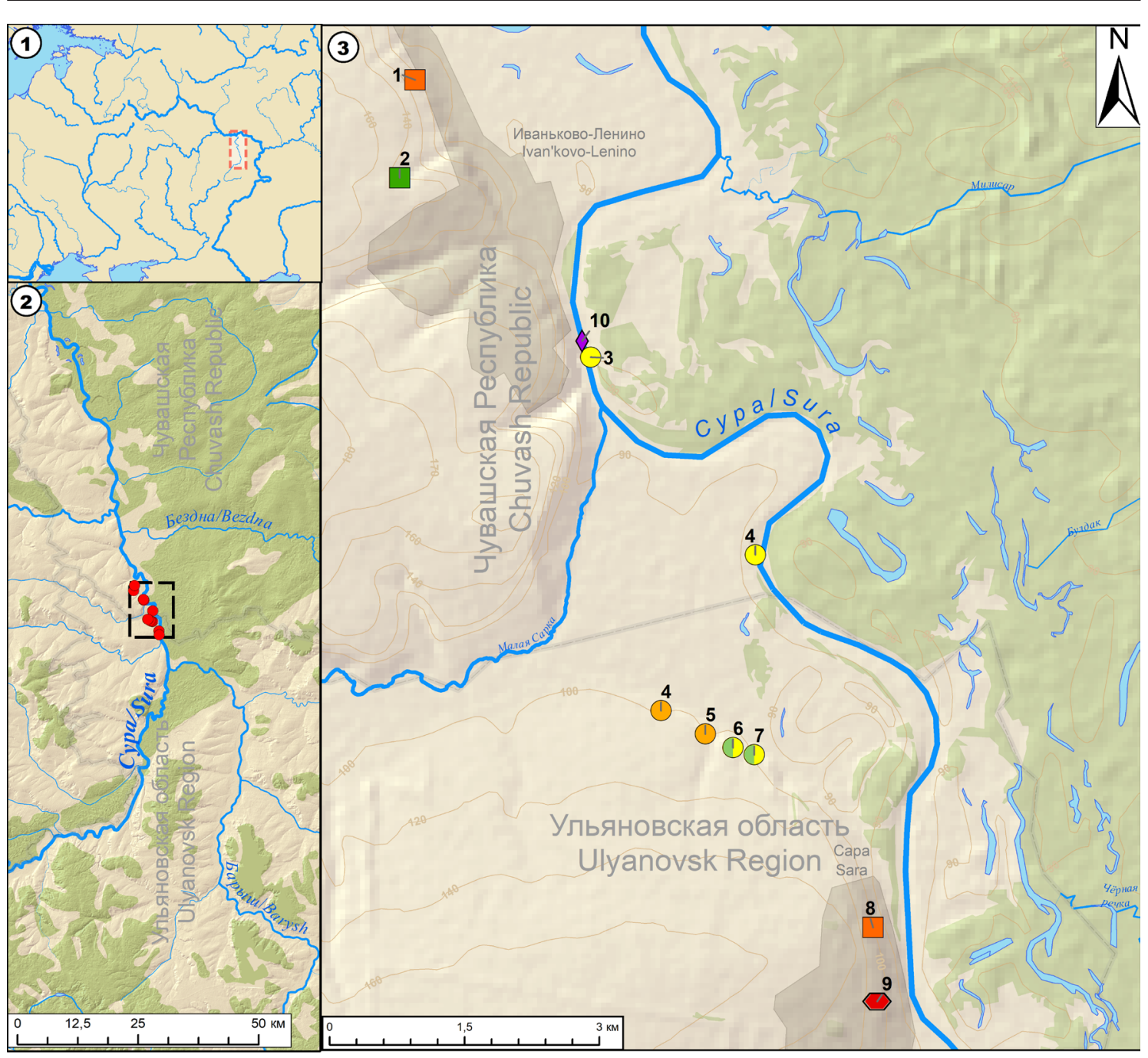

\section{Условные обозначения / Legend:}

$\checkmark$ местнонахождение, VIII-IV вв. до н.э. I find, 800-300 BCE

городище, 1-я четв. I тыс. н.э. / hillfort, 0 $250 \mathrm{CE}$

сепище, 2-я четв. І тыс. н.э. / settlement, 250-500 CE

селище, 1-я четв. I тыс. н.э; 2 четв. I

тыс. н.э. / settlement, 0-250; 250-500 CE селище, 2-3 (?) четв. I тыс. н.э. I
settlement, 250-500, 500-700 CE

городище, 3-я четв. I тыс. н.э. / hillfort, 500-700 CE

селище и могильник, II тыс. н.э. I settlement and necropolis, later $1250 \mathrm{CE}$
Современные населенные пункты Modern localities

Залесенные территории / Forest

Озера / Lakes\&oxbows

Изолинии (через 20 м) / Contours (20 m step)

Puc. 1. Микрорегион исследований в нижнем течении p. Малая Сарка (Среднее Посурье).

Цифрами на карте обозначены: 1 - Иваньково-Ленинское городище Шолм; 2 - Городище Иваньковская Стрелка; 3 - Макеевское селище; 4 - Селище Устье Малой Сарки; 4 - Селище Сара-4; 5 - Селище Сара-3; 6 - Селище Сара-2; 7 - Селище Сара-1; 8 - Городище Лодыжья гора; 9 - Селище Сара-5 и грунтовый могильник; 10 - находка на Макеевском селище.

[Fig. 1. Area of study downstream the Malaya Sarka River (Middle Sura region).

Figures indicate as follows: 1 - Ivankovo-Lenino hillfort of Sholm; 2 - Ivankovskaya Strelka hillfort; 3 Makeevskoe site; 4 - Ustye Maloy Sarki (Malaya Sarka Estuary) site; 4 - Sara-4 site; 5 - Sara-3 site; 6 - Sara-2 site; 7 - Sara-1 site; 8 - Lodyzhya Gora hillfort; 9 - Sara-5 settlement and burial ground; 10 - find from Makeevskoe site] 


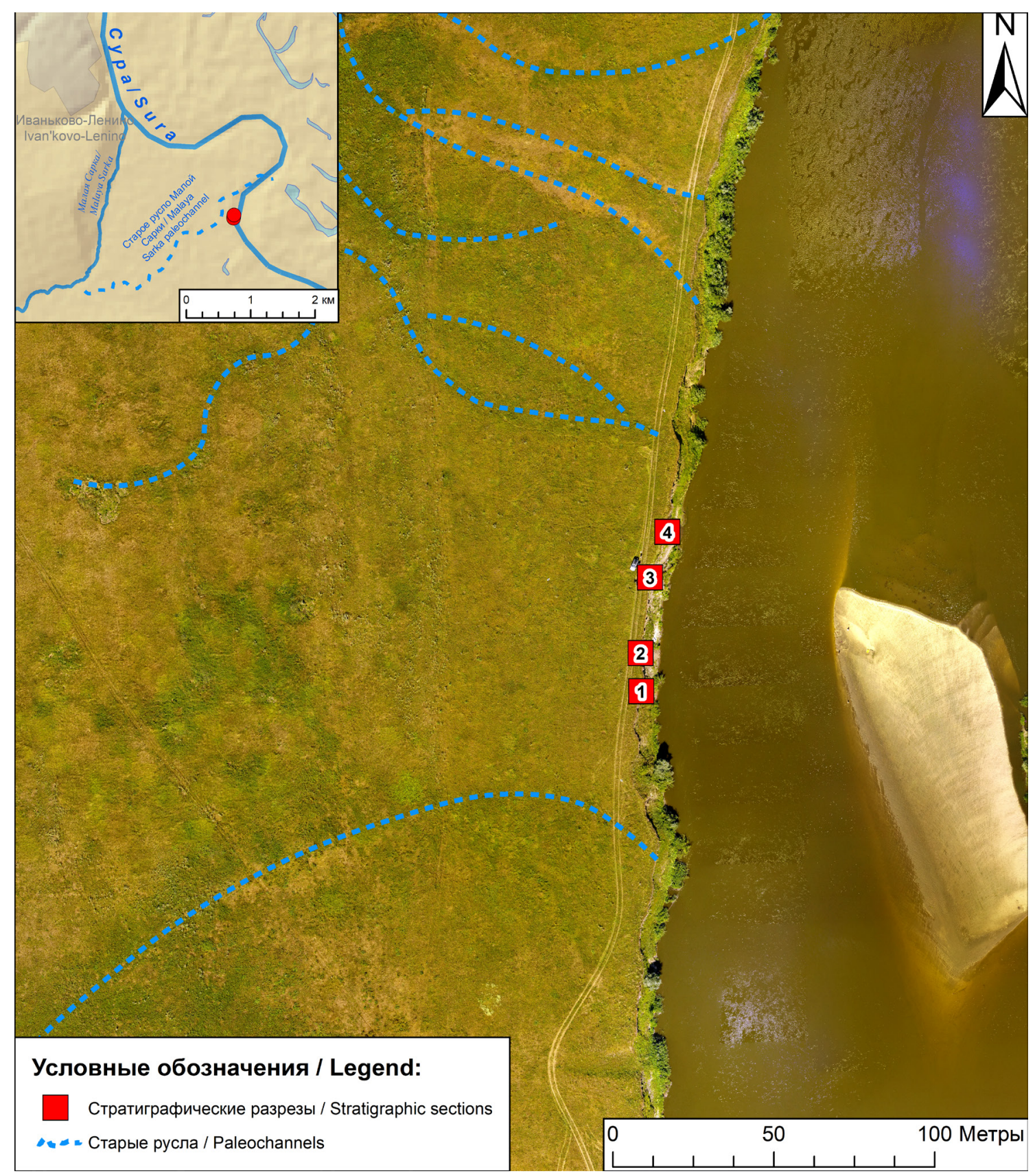

Рис. 2. Селище Устье Малой Сарки. Ортофотоплан поверхности

[Fig. 2. Ustye Maloy Sarki (Malaya Sarka Estuary) site. Orthophotomap of the surface]

4) в V-VII вв. н. э. - именьковским населением;

5) в XIV в. н. э. - золотоордынским, мордовским и позднее русским населением.

\section{Материалы и методы исследования}

В ходе обследования Иваньковского микрорегиона в 2015-2019 гг. было отмечено, что из всех периодов освоения именно материалы III-IV вв. н. э. наиболее массово встречаются в пойменных участках Сурской долины, в том числе - в слоях, перекрытых позднейшими аллювиально-пролювиальными отложениями. Для изучения взаимосвязи динамики флювиальных и историко-культурных процессов экспедицией был выполнен поиск береговых обнажений, содержащих погребенные культурные слои.

В результате был выбран участок, расположенный в береговом обрыве р. Суры 
в 3 км к юго-востоку от с. Иваньково-Ленино и в 4 км к северу-северо-западу от с. Сара, где краевед с. Иваньково А. А. Макеев с 1970-х гг. фиксировал фрагменты керамики в слое, перекрытом позднейшими наносами. Осмотр обнажения подтвердил наличие погребенного культурного слоя, содержащего угли и фрагменты керамики, маркирующие наличие археологического памятника поселенческого типа. Посколь- ку, согласно картам XIX в., выявленный памятник находится в непосредственной близости от исторического устья р. Малая Сарка, он получил название «Селище „Устье Малой Сарки“»».

Для изучения пойменных отложений, вмещающих культурный слой памятника, были сделаны четыре зачистки (пойменные разрезы 1-4). Найденная при зачистке в погребенном культурном слое керамика
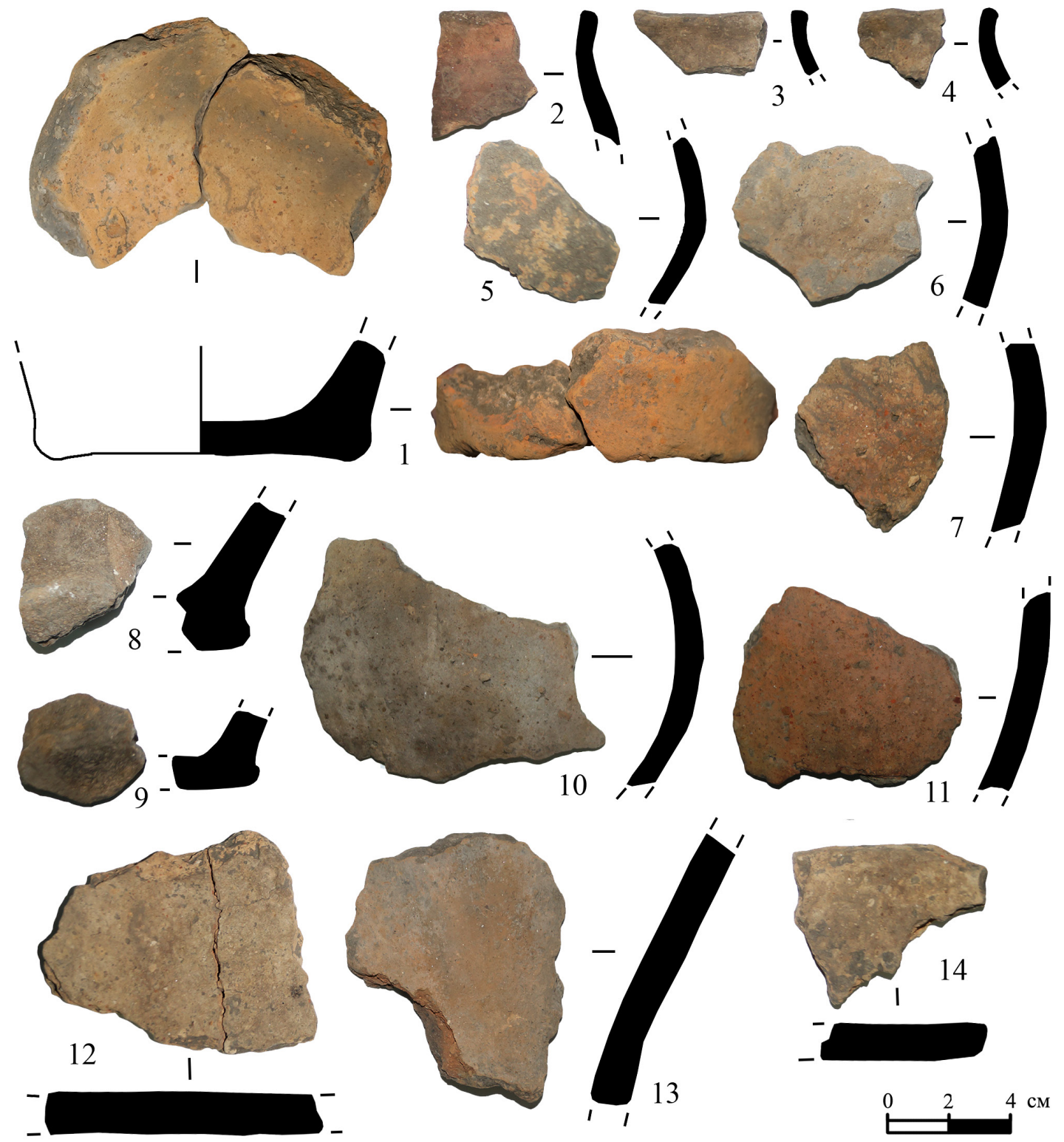

Рuc. 3. Комплекс находок из заполнения котлована (разрез 4) и культурного слоя селища Устье Малой Сарки. 1-14 - лепная керамика.

[Fig. 3. Finds from the in-fill of the structure in Section 4 and from the cultural layer of Ustye Maloy Sarki (Malaya Sarka Estuary) site. 1-14 — handmade pottery] 
представлена фрагментами толстостенных плоскодонных лепных сосудов с примесью шамота (рис. 3: А). Шейки короткие, слабопрофилированные, без выраженного уступа при переходе к тулову (рис. 3: 9-11); переход к днищу прямой или в виде небольшой закраины (рис. 3: 1, 6). Наибольшее расширение тулова часто оформлено в виде сглаженного ребра (рис. 3: 3, 5, 7, 8). Такой набор признаков характерен для средневолжского варианта киевской культуры — время формирования культурного слоя можно отнести ко 2-й четверти I тыс. н. э.

Исследование пойменных отложений, вмещающих культурный слой селища Устье Малой Сарки, показало наличие нескольких этапов эрозии и осадконакопления. Для верификации полученных результатов экспедицией был заложен еще один разрез, вскрывающий толщу стратифицированных овражно-балочных отложений на дне безымянного оврага, разделяющего

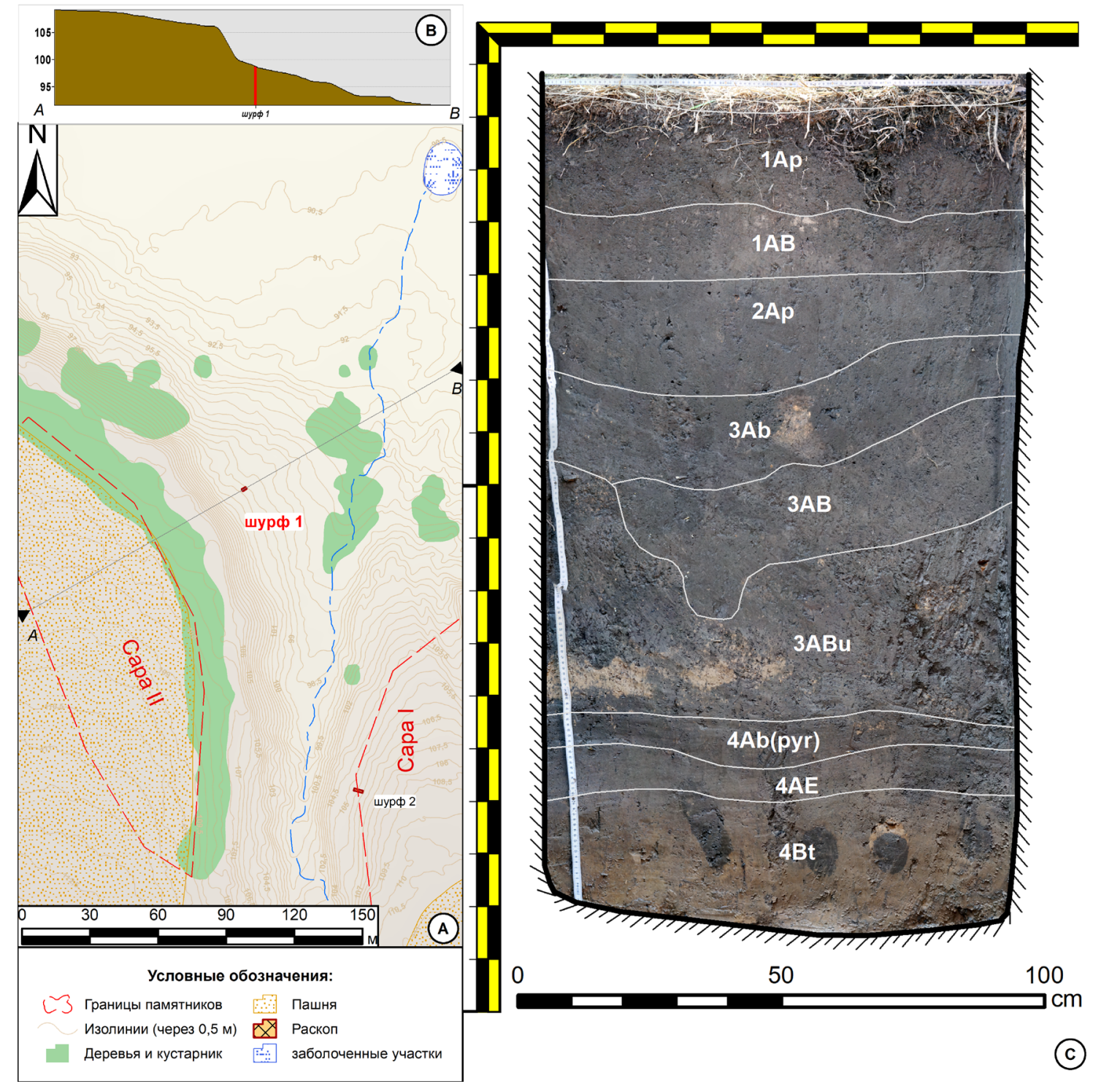

Puc. 4. Шурф в устье безымянного оврага у селищ Capa-1 и 2.

A - место закладки шурфа, топографический план; В — профиль высот склона надпойменной террасы р. Суры по линии АВ; C — стратиграфия шурфа (западная стенка)

[Fig. 4. Test pit in the mouth of unnamed gully at Sara-1, 2 sites.

A - topographic map of the area where the test pit was elaborated; B - elevation profile of the terrace slope from point A to B; C - stratigraphy of the test pit (western wall)] 
селища Capa-1 и Capa-2, у подножия террасы, был заложен дополнительный разрез (иурф 1). Стратиграфические данные, полученные в шурфе 1 , позволили сопоставить количество этапов эрозии в овражно-балочных и пойменных отложениях (рис. 4).

Артефакты из шурфа 1 (рис. 5: 11-14) представлены фрагментами лепных плоскодонных сосудов с примесью шамота. Присутствуют сосуды со слабопрофилированной шейкой и со сглаженным ребром (рис. 5: 14) и венчики с утолщением на крае (рис. 5: 12). Обнаруженная керамика близка к выявленной в культурном слое селища Устье Малой Сарки (рис. 3) и на селищах Cара-1 и 2 (рис. 5: 1-10), что позволяет синхронизировать эти памятники.
Стратиграфия всех выполненных разрезов документировалась методом цифровой фотофиксации с последующим ортотрансформированием снимков и получением сводного ортофотоплана в программе Agisoft Photoscan. Для названия горизонтов использовалась номенклатура WRB [IUSS 2015]. Из выделенных стратиграфических слоев отбирались пробы для археоботанических определений. Обработка пространственных данных осуществлялась с использование средств программного пакета ArcGIS.

Относительная хронология строилась на основании стратиграфических наблюдений и культурно-археологических данных о регионе. Абсолютное датирование угля
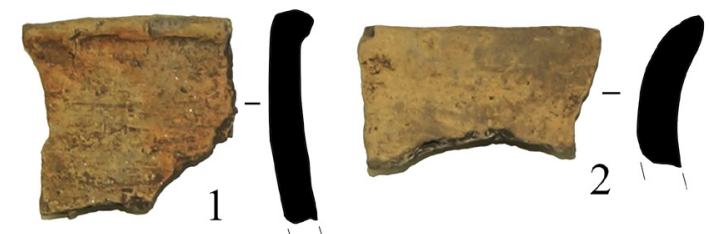

2
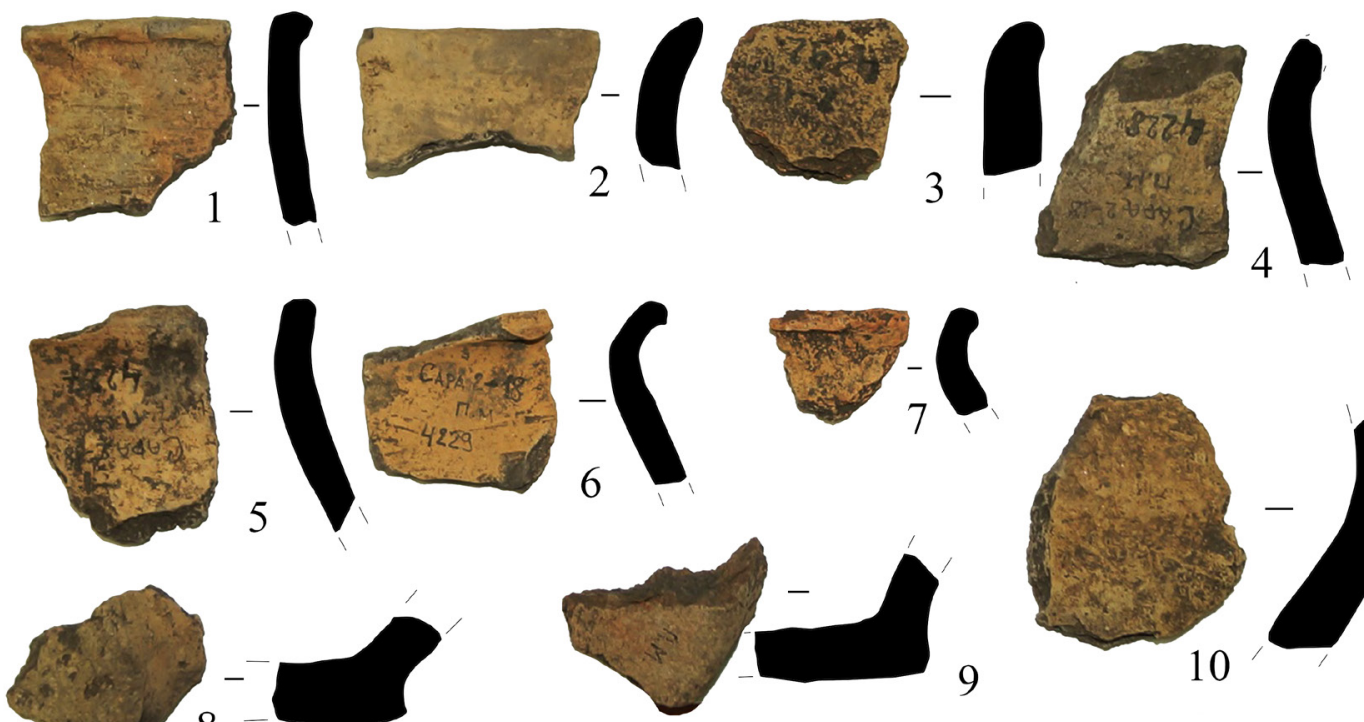

7
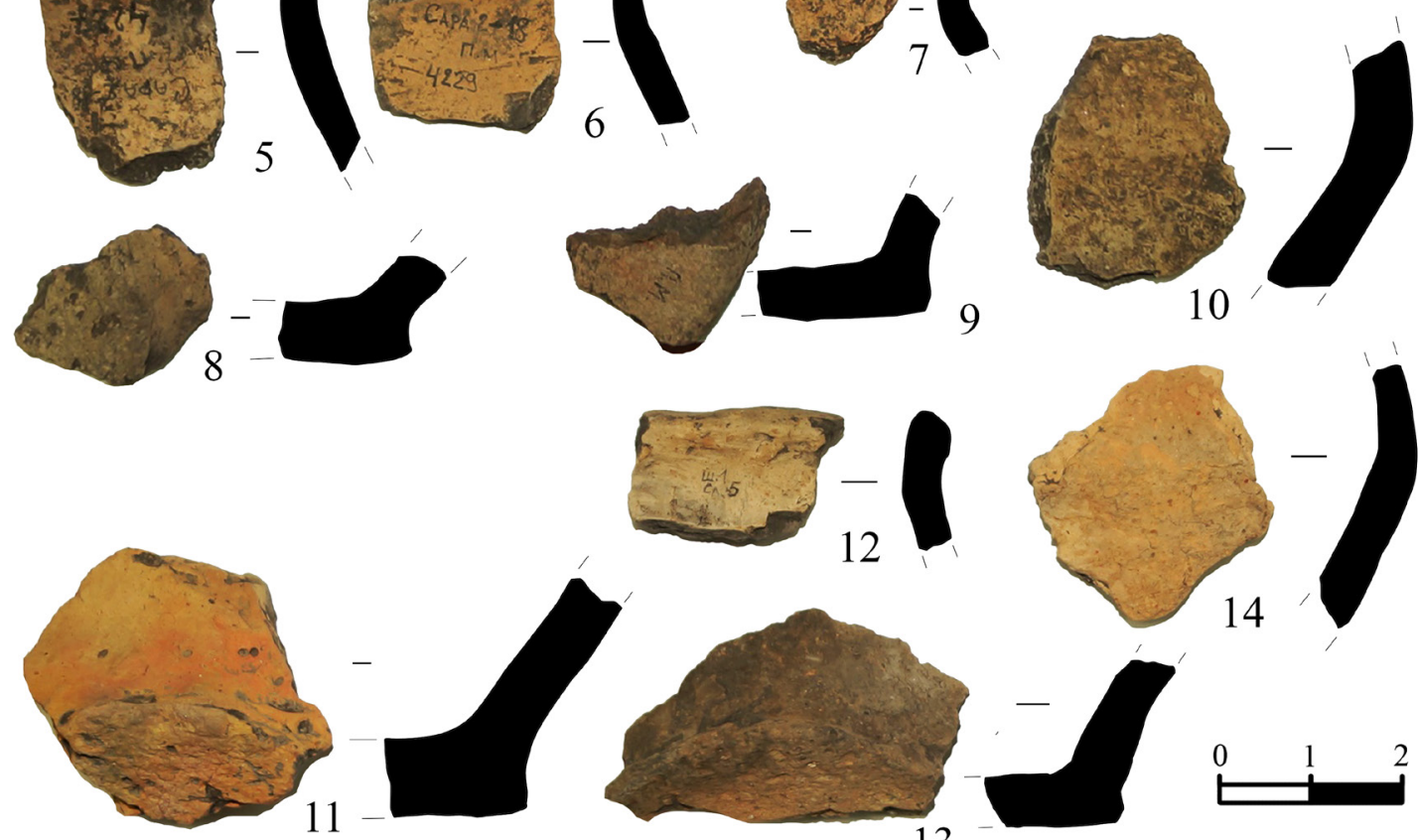

12
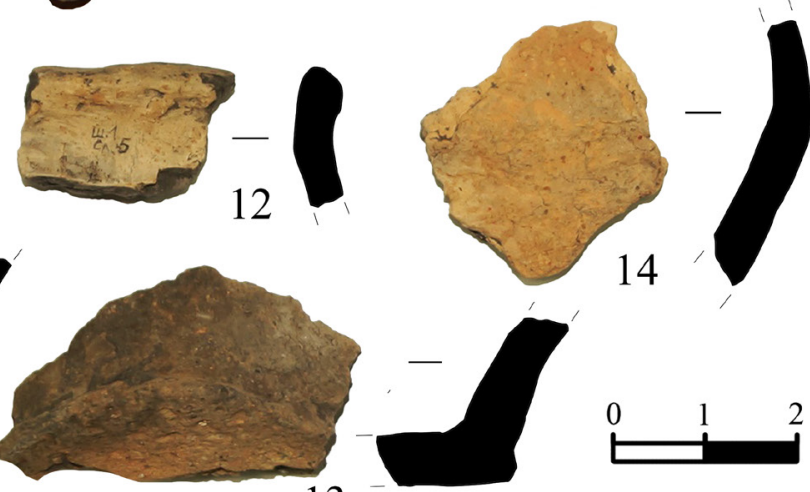

13
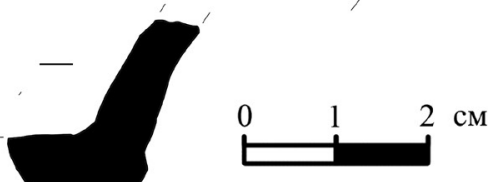

Puc. 5. Комплекс находок из шурфа $1(11-14)$ и подъемный материал с поверхности селища Capa-2 (1-10). 1-15 - лепная керамика

[Fig. 5. Finds from the test pit $1(11-14)$ and surface finds from Sara-2 site (1-10). 1-15 - handmade pottery] 
методом AMS проводилось в Лаборатории им. А. Е. Лалонда (Оттавский университет, Канада).

I. Стратиграфия пойменных разрезов на селище Устье Малой Сарки

Для изучения культурного слоя селища и вмещающих его пойменных отложений были сделаны четыре зачистки берегового обнажения р. Суры. Во всех разрезах прослеживаются несколько погребенных дневных поверхностей (молодых почв), пе- рекрытых пачками аллювиальных наносов (табл. 1; рис. 6). В процессе исследования выявленные пачки слоев получили нумерацию с I до V в порядке сверху вниз, т. е. от более молодой к более древней; современная поверхность получила номер 0. Стратиграфические слои получили кодовые обозначения в соответствии с номенклатурой WRB [IUSS 2015], принадлежность слоев к той или иной пачке отражена римской цифрой в названии слоя.

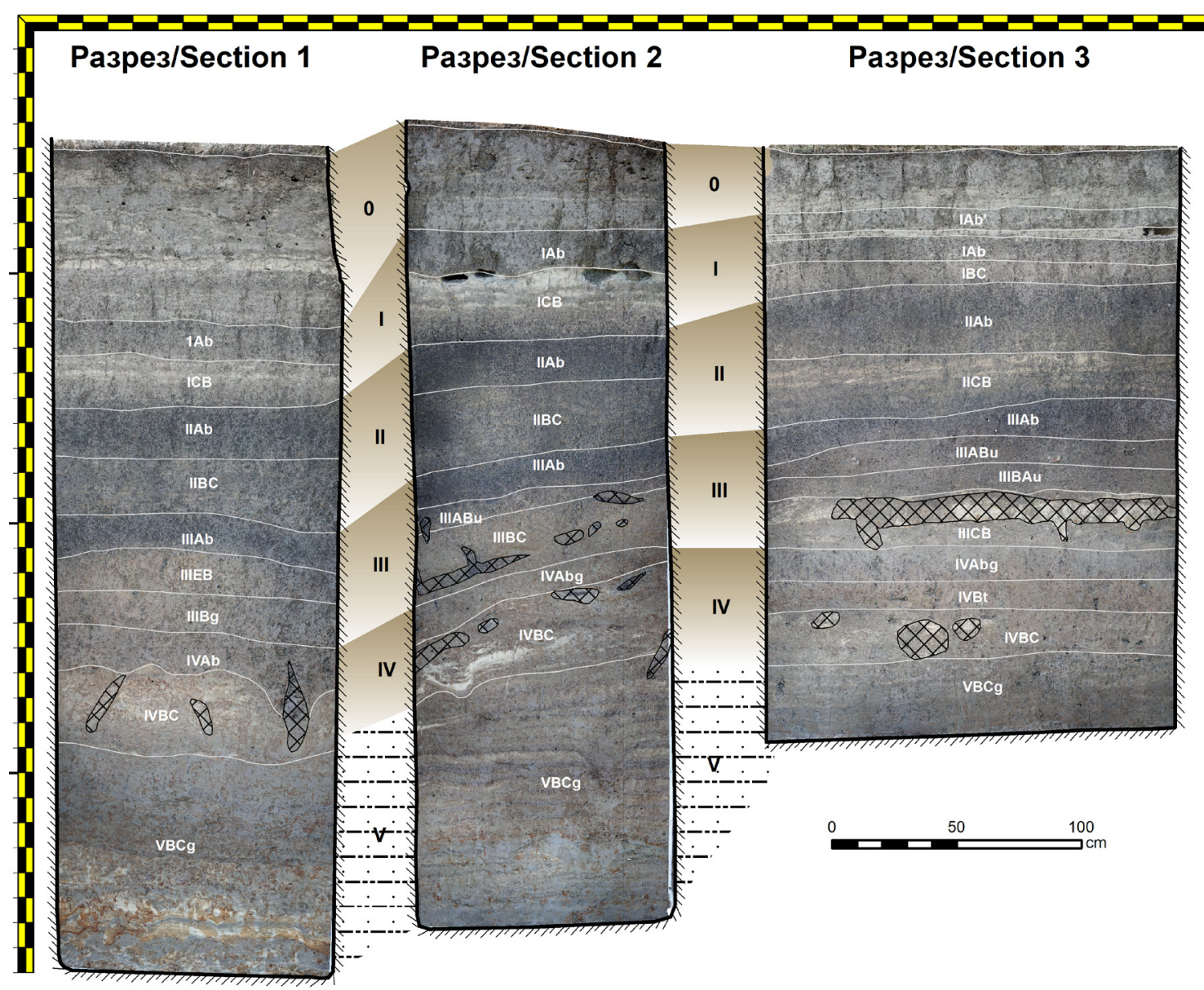

Puc. 6. Стратиграфия разрезов 1-3

[Fig. 6. Stratigraphic profiles for sections 1-3] 
Oriental Studies. 2021. Vol. 14. Is. 5

Таблица 1. Стратиграфия пойменных разрезов 1-4 на селище Устье Малой Сарки

\begin{tabular}{|c|c|c|c|c|c|c|c|c|}
\hline \multirow[b]{2}{*}{ № } & \multicolumn{2}{|r|}{ Слой } & \multicolumn{3}{|c|}{ Разрез 1} & \multicolumn{3}{|c|}{ Разрез 2} \\
\hline & Код & Описание & ГЛ. & M. & особенности & гЛ. & M. & особ. \\
\hline 0 & & $\begin{array}{l}\text { Современная почва, развитая на песчаных аллю- } \\
\text { виально-пролювиальных наносах с протяженны- } \\
\text { ми светлыми прослоями песка и гумусированны- } \\
\text { ми прослоями переотложенного эродированного } \\
\text { почвенного материала (мощностью до } 5 \text { см). В } \\
\text { некоторых из них есть следы жизнедеятельности } \\
\text { наземных беспозвоночных }\end{array}$ & 0 & 70 & + & 0 & 40 & + \\
\hline \multirow{3}{*}{ I } & $I A b$ & $\begin{array}{l}\text { Гумусовый горизонт, заиленный песок серо- } \\
\text { палевого цвета, структура зернистая }\end{array}$ & \multirow{3}{*}{0,7} & $13-16$ & + & \multirow{3}{*}{0,4} & $\begin{array}{c}16- \\
19 \\
\end{array}$ & + \\
\hline & $I B C$ & $\begin{array}{l}\text { Пачка песчаных аллювиальных наносов, переме- } \\
\text { шанных биотой, слоистость сохранилась локаль- } \\
\text { но }\end{array}$ & & - & 一 & & - & 一 \\
\hline & $I C B$ & $\begin{array}{l}\text { Слоистая аллювиально-пролювиальная толща, } \\
\text { частично перемешанная почвенной биотой }\end{array}$ & & $16-24$ & + & & $\begin{array}{c}25- \\
29 \\
\end{array}$ & + \\
\hline \multirow{3}{*}{ II } & $I I A b$ & $\begin{array}{l}\text { Гумусовый горизонт темно-серого цвета, легкий } \\
\text { суглинок, структура зернистая }\end{array}$ & \multirow{3}{*}{1} & $20-22$ & $\begin{array}{c}\text { ровная нижняя } \\
\text { граница несет } \\
\text { следы подрезки } \\
\text { пахотными } \\
\text { орудиями }\end{array}$ & \multirow{3}{*}{0,85} & 18 & + \\
\hline & IIBC & $\begin{array}{l}\text { Пачка перемешанных биотой суглинистых нано- } \\
\text { сов с включениями крупных фрагментов древес- } \\
\text { ного угля }\end{array}$ & & $23-30$ & $\begin{array}{c}\text { мощность } \\
\text { прослоев } \\
\text { 9-13 мм, цвет } \\
\text { желтовато- } \\
\text { палевый и } \\
\text { темно-серый }\end{array}$ & & $\begin{array}{c}25- \\
33\end{array}$ & $\begin{array}{c}\text { прослои 5-8 мм } \\
\text { коричневато- } \\
\text { палевого цвета, } \\
\text { на большей } \\
\text { части стенки } \\
\text { перемешаны } \\
\text { почвенной биотой }\end{array}$ \\
\hline & $I I C B$ & $\begin{array}{l}\text { Пачка суглинистых и песчаных аллювиальных } \\
\text { наносов, локально перемешанных биотой }\end{array}$ & & - & - & & - & - \\
\hline \multirow{6}{*}{ III } & IIIAb & $\begin{array}{l}\text { Гумусовый горизонт однородного темно-серо- } \\
\text { го цвета, легкий суглинок, структура зернистая, } \\
\text { единичные крупные фрагменты древесного угля }\end{array}$ & \multirow{6}{*}{1,4} & $14-18$ & + & \multirow{6}{*}{$\begin{array}{c}1,1- \\
1,4\end{array}$} & 14 & + \\
\hline & IIIApyr & $\begin{array}{l}\text { Слой средне-серого гумусированного, углистого } \\
\text { песка }\end{array}$ & & - & 一 & & - & - \\
\hline & IIIBu(1) & $\begin{array}{l}\text { Заполнение котлована постройки (шир. } 1,1 \text { м); } \\
\text { перемешанный землероями песок с сохранивши- } \\
\text { мися следами тонкой (<4 мм) слоистости, содер- } \\
\text { жит артефакты, кости животных и угли }\end{array}$ & & - & - & & - & - \\
\hline & IIIAu & $\begin{array}{l}\text { Неоднородно-окрашенный гумусированный лег- } \\
\text { кий суглинок, слоистость отсутствует, зернистая } \\
\text { структура, включения спекшихся комков ожелез- } \\
\text { ненного песка и суглинка, углей и фрагментов } \\
\text { лепной керамики - культурный слой }\end{array}$ & & - & - & & 10 & $\begin{array}{c}\text { в нижней части } \\
\text { встречаются } \\
\text { единичные норы } \\
\text { землероев (d=3-5 } \\
\text { см) } \\
\end{array}$ \\
\hline & IIIABu & $\begin{array}{l}\text { Темно-серый перемешанный песок с } \\
\text { включениями ожелезненных комков суглинка, } \\
\text { насыщен фрагментами угля и артефактами }\end{array}$ & & - & - & & - & - \\
\hline & IIIBAu & $\begin{array}{l}\text { Темно-серый перемешанный песок, } \\
\text { насыщенный фрагментами угля и артефактами }\end{array}$ & & - & - & & - & - \\
\hline
\end{tabular}


[Table 1. Stratigraphic profiles for floodplains 1-4 at Ustye Maloy Sarki settlement]

\begin{tabular}{|c|c|c|c|c|c|}
\hline \multicolumn{3}{|r|}{ Разрез 3} & \multicolumn{3}{|r|}{ Разрез 4} \\
\hline гл. & M. & особенности & гл. & M. & особенности \\
\hline 0 & 35 & $\begin{array}{c}\text { описана молодая дерновая } \\
\text { почва с гумусовым горизонтом } \\
\left.\text { (IA } \boldsymbol{b}^{\prime}\right)(8-10 \text { см) }\end{array}$ & 0 & 50 & + \\
\hline \multirow{3}{*}{0,35} & 10 & + & \multirow{3}{*}{0,5} & $8-14$ & + \\
\hline & $9-13$ & $\begin{array}{c}\text { переслаивающиеся наносы } \\
\text { гумусированного песка и бо- } \\
\text { лее светлого легкого суглинка, } \\
\text { перемешаны на большей части } \\
\text { слоя } \\
\end{array}$ & & - & - \\
\hline & - & - & & $8-14$ & + \\
\hline \multirow{3}{*}{0,5} & 28 & + & \multirow{3}{*}{0,7} & 20 & + \\
\hline & - & - & & $76-115$ & $\begin{array}{c}\text { аллювиальные суглинистые и песчаные прослои внутри } \\
\text { этой пачки имеют бо́льшую мощность (1-7 см) по } \\
\text { сравнению с аналогичными прослоями разрезов 1-3 за } \\
\text { счет заполнения аллювием глубокой эрозионной врезки в } \\
\text { нижележащую пачку слоев }\end{array}$ \\
\hline & $\begin{array}{c}17- \\
26 \\
\end{array}$ & тонкие (до 1 см) прослои & & - & - \\
\hline \multirow{6}{*}{1} & $8-17$ & + & \multirow{6}{*}{$\begin{array}{c}1,7- \\
2,1\end{array}$} & $10-44$ & + \\
\hline & - & - & & 8 & Правая часть разреза \\
\hline & - & - & & 70 & $\begin{array}{c}\text { Верхняя часть заполнения котлована перемешана сильнее, } \\
\text { до почти гомогенного состояния, дно его не несет следов } \\
\text { утаптывания }\end{array}$ \\
\hline & - & - & & - & - \\
\hline & $8-12$ & + & & $10+-17$ & + \\
\hline & $8-10$ & $\begin{array}{l}\text { мелкая пятнистость окраски } \\
\text { из-за многочисленных } \\
\text { субвертикальных ходов } \\
\text { беспозвоночных (d=4-7 мм) }\end{array}$ & & - & - \\
\hline
\end{tabular}


Oriental Studies. 2021. Vol. 14. Is. 5

\begin{tabular}{|c|c|c|c|c|c|c|c|c|}
\hline \multirow[b]{2}{*}{ № } & \multicolumn{2}{|r|}{ Слой } & \multicolumn{3}{|c|}{ Разрез 1} & \multicolumn{3}{|c|}{ Разрез 2} \\
\hline & Код & Описание & гл. & M. & особенности & гл. & M. & особ. \\
\hline & $I I B B u(2)$ & $\begin{array}{l}\text { Тонкослоистые аллювиальные наносы светлого } \\
\text { песка с включениями мелких (2-4 мм) пятен су- } \\
\text { глинка и ожелезненными включениями-заполне- } \\
\text { ние котлована постройки }\end{array}$ & & - & - & & - & - \\
\hline & IIIBC & $\begin{array}{l}\text { Песчаный нанос коллювиально-аллювиального } \\
\text { происхождения, перемешан землероями, } \\
\text { слоистость сохранилась локально }\end{array}$ & & - & - & & $\begin{array}{c}22- \\
25\end{array}$ & + \\
\hline & IIICB & $\begin{array}{l}\text { Песчаный нанос аллювиального происхождения, } \\
\text { содержащий ожелезненные включения, с } \\
\text { большой долей отбеленного песка, замешан } \\
\text { позвоночными землероями по ходам d=7-9 см }\end{array}$ & & - & - & & - & - \\
\hline & IIIEB & Белесо-палевый легкий суглинок & & $10-15$ & + & & - & - \\
\hline & IIIBg & $\begin{array}{l}\text { Оглеенный голубовато-серый средний суглинок } \\
\text { с многочисленными охристыми железистыми } \\
\text { включениями }\end{array}$ & & $20-25$ & + & & - & - \\
\hline \multirow{4}{*}{ IV } & $I V A b$ & $\begin{array}{l}\text { Гумусовый горизонт, песок палево-серого цвета, } \\
\text { бесструктурный }\end{array}$ & \multirow{4}{*}{1,9} & $13-20$ & $\begin{array}{c}\text { В слое и вдоль } \\
\text { его верхней } \\
\text { границы с } \\
\text { кроющим } \\
\text { наносом } \\
\text { отмечены норы } \\
\text { землероев } \\
\text { (d=5-6 см) } \\
\end{array}$ & \multirow{4}{*}{$\begin{array}{c}1,7- \\
1,8\end{array}$} & - & - \\
\hline & IVAbg & $\begin{array}{l}\text { Голубовато-серый гумусированный, оглееный } \\
\text { оглиненный песок }\end{array}$ & & - & - & & $6-16$ & $\begin{array}{c}\text { поверхность } \\
\text { эродирована, } \\
\text { из почвы II } \\
\text { спускаются ходы } \\
\text { землероев (d=5-6 } \\
\text { см) }\end{array}$ \\
\hline & IVBt & $\begin{array}{l}\text { Охристо-бурый опесчаненный суглинок, } \\
\text { структура ореховатая }\end{array}$ & & - & - & & - & - \\
\hline & $I V B C$ & $\begin{array}{l}\text { Песчаный нанос, содержащий слои темно- } \\
\text { серого цвета с железистыми включениями, } \\
\text { перемежающиеся с прослоями светлого песка, } \\
\text { аллювиально-пролювиального происхождения }\end{array}$ & & $30-34$ & $\begin{array}{c}\text { локально } \\
\text { сохранились } \\
\text { небольшие } \\
\text { фрагменты } \\
\text { исходной ал- } \\
\text { лювиальной } \\
\text { слоистости с } \\
\text { линзами круп- } \\
\text { нозернистого } \\
\text { песка, переме- } \\
\text { шанные биотой } \\
\text { на большей } \\
\text { части слоя } \\
\end{array}$ & & $\begin{array}{c}28- \\
37\end{array}$ & $\begin{array}{c}\text { значительно } \\
\text { перемешаны } \\
\text { землероями }\end{array}$ \\
\hline $\mathrm{V}$ & $V B C g$ & $\begin{array}{l}\text { Толща слоистых суглинисто-песчаных озерно- } \\
\text { старичных отложений }\end{array}$ & 2,3 & $>1 \mathrm{M}$ & $\begin{array}{c}\text { слоистость } \\
\text { локально } \\
\text { нарушена } \\
\text { педотурбацией }\end{array}$ & 2,15 & $\begin{array}{c}>1 \\
\mathrm{M}\end{array}$ & + \\
\hline
\end{tabular}

Примечания: Пачки слоев: I — первая погребенная почва; II — вторая погребенная почва; III - третья погребенная почва; IV — четвертая погребенная почва; V — озерно-старичные отложения.

Гл. — глубина (в метрах), м. — мощность (в см), особ. — особенности 


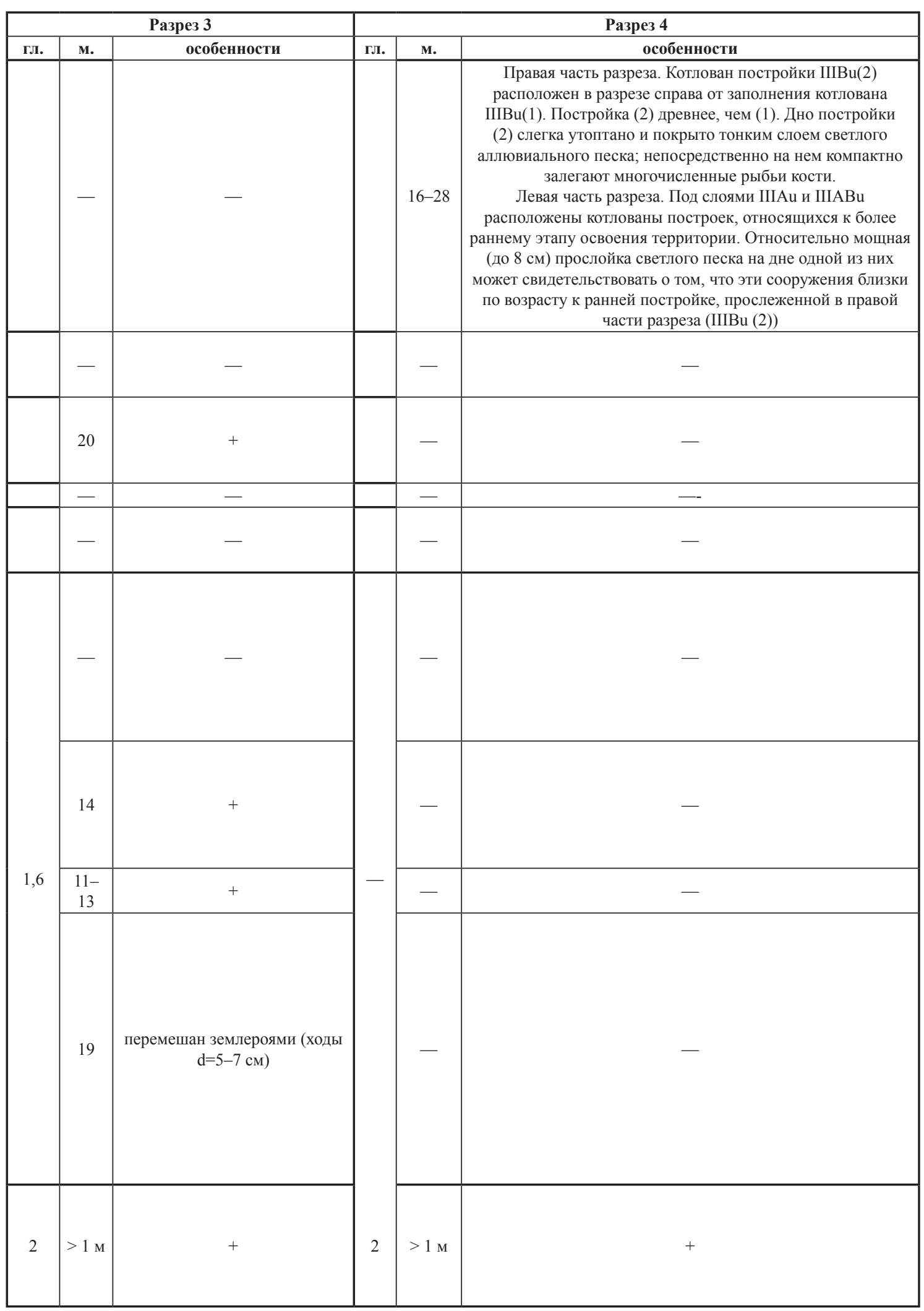




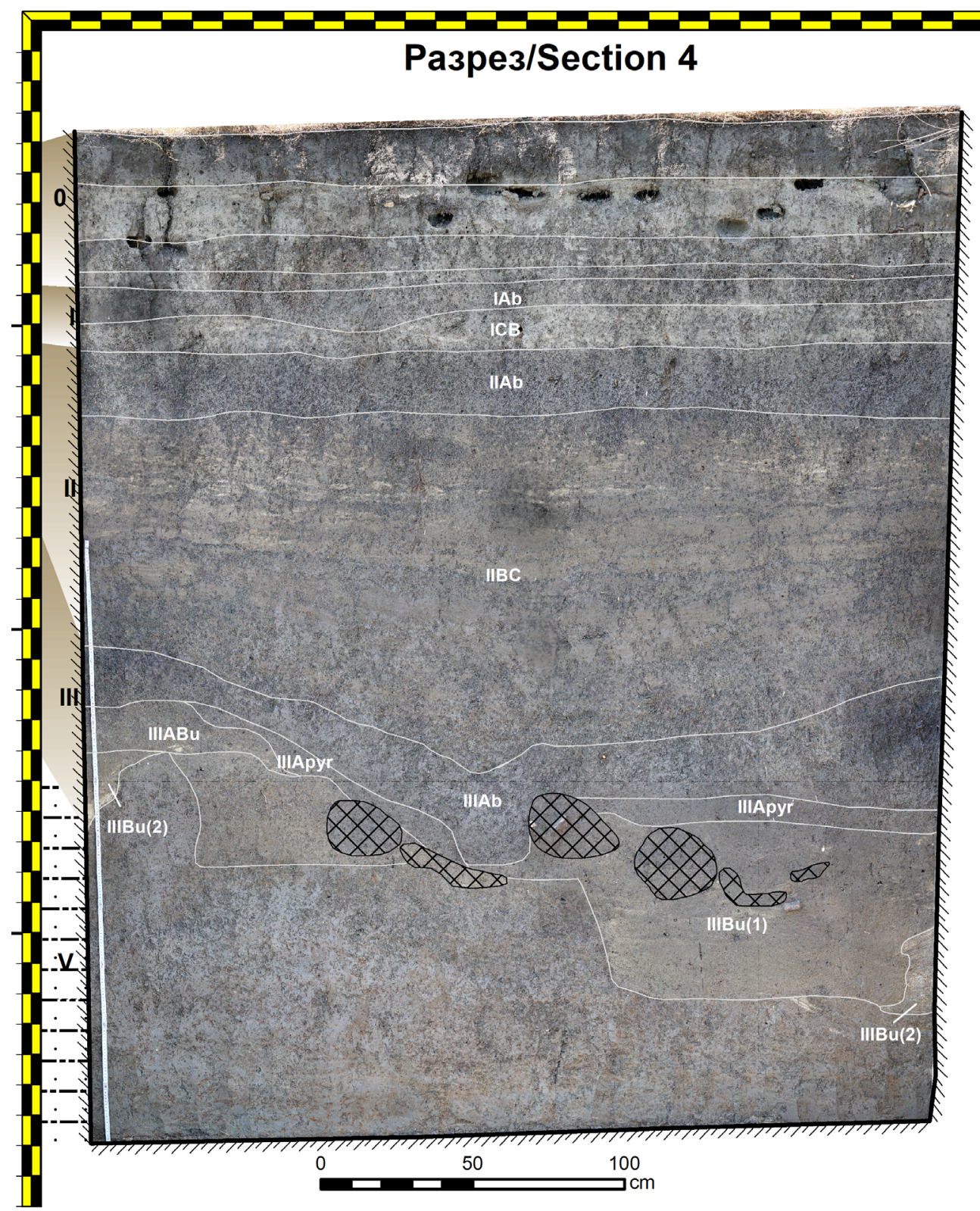

Рuc. 7. Стратиграфия разреза 4

[Fig. 7. Stratigraphic profile for section 4]

Несмотря на отдельные отличия, все разрезы отражают общие процессы. Выделяются 5 древних и современный циклы осадконакопления (соответствие слоев циклам см. табл. 1); в четырех из этих циклов начальный этап активной поемности и накопления аллювия сменяется низкой поемностью, стабилизацией поверхности и формированием погребенной почвы, маркирующей ту или иную продолжительность стабилизации. Ниже приведена краткая характеристика этих циклов, от наиболее древнего к наибо- лее молодому, то есть в хронологическом порядке их формирования.

\section{Цикл V (гл. 200-235 см)}

В основании разрезов залегает полосчатая толща тонко- и среднезернистых песков с суглинистыми прослоями мощностью от 1 до 5 см, границы между прослоями ровные, выдержаны по простиранию, слои оглеены - округлые пятна и линейные морфоны с железистым ободком маркируют садку железа вокруг корней. Погребенные дневные поверхности не обнаружены, 
но в разрезе 1 мощность прослоев очень невелика - они почти смыкаются, что может свидетельствовать о наличии здесь болотно-глеевой почвы, срезанной эрозией. Верхняя граница пачки эрозионная, с перепадами уровней до 10 см, что говорит о быстром, резком изменении режима поемности. Характер выявленных напластований, таким образом, позволяет интерпретировать слои цикла V как наносы, которые отложились в стоячей воде пойменного озера, пересохшего и заболотившегося к кониу ичкла.

\section{Цикл IV (гл. 160-200 см)}

Эта пачка слоев представлена только в разрезах 1 и 3, в разрезе 4 она прорезана углубленными сооружениями селища, а в разрезе 2 сильно размыта. Пачка состоит из опесчаненного суглинка, преобразованного почвообразованием: с протяженными линзами песка в нижней части, прерывистыми линзами и пятнами в средней части и погребенного серо-гумусового горизонта IVAb мощностью 7-9 см. В нижней и верхней частях пачки есть оглеение по корневинам; в подгумусовом слое отмечена ореховатая структура, характерная для лесных почв: по-видимому, эта дерново-глеевая почва прошла лесную стадию почвообразования.

Границы между прослоями в средней и нижней части пачки эрозионные, прослои прослеживаются на протяжении 10-20 см. Верхняя граница пачки нарушена антропогенной деятельностью в двух из четырех разрезов; в разрезе 1 граница между погребенной почвой и кроющим наносом постепенная, что может свидетельствовать о постепенном увеличении продолжительности затопления в конце цикла. Таким образом, цикл IV отражает переход участка в режим поемности - врезание русла и периодическое затопление участка паводковыми водами.

\section{Цикл III (гл. 200-150 см)}

Пачка состоит из суглинка, полностью преобразованного почвообразованием; слоистость отсутствует, верхние 12-15 (до 40 см) имеют темно-серую окраску и зернистую структуру (погребенный гумусовый горизонт IIIAb). Слои, связанные с хозяйственной деятельностью населения, оставившего селище Устье Малой Сарки, залегают в этой пачке, под гумусовым горизонтом. Особняком стоит разрез 1, где слои, содержащие артефакты, в составе III пачки не выявлены. Верхняя граница пачки эрозионная, с перепадами до 50 см, что говорит о быстром, резком изменении режима поемности в конце цикла. Этот период характеризуется длительной стабилизацией поверхности и низкой поемностью (режим, при котором пойма затопляется непродолжительно или не каждый год).

\section{Цикл II (гл. 1,0-0,6 м)}

Пачка чередующихся прослоев светлого тонкозернистого песка и более темного суглинка, мощность прослоев от 1 до 8 см; верхние 10-15 см гумусированы, имеют насыщенную темно-серую окраску и зернистую копрогенную структуру (погребенный гумусовый горизонт IIAb), с поверхности опущены заполненные ходы землероев диаметром около 7 см. Интенсивно-темная окраска гумусового горизонта при отсутствии явной углистости и обилие землероин характерны для степного типа гумусонакопления, почва лугово-черноземная. Нижняя граница пачки эрозионная, верхняя - достаточно ровная, что говорит о постепенном увеличении водности в конце цикла. Формирование травяной экосистемы (остепненный луг?) в пойме.

\section{Цикл I (гл. 1,0-0,6 м)}

Пачка чередующихся прослоев светлого тонкозернистого песка и гумусированной супеси, мощность прослоев от 2 до 10 см слоистый аллювий, характерный для сельскохозяйственного освоения (распашки) водосборного бассейна; верхние 13-18 см перемешаны и гумусированы, с бледно-серой окраской — погребенный гумусовый горизонт IAb c нижней границей, в некоторых разрезах подрезанной пахотными орудиями - cтаропахотная дерновая почва. Округлые копрогенные агрегаты организованы в пластинчатую структуру за счет поверхностного уплотнения. Верхняя граница слоя ровная, резкая, маркируется наносом песка на гумусированную поверхность. В течение цикла произошло стремительное увеличение стока и распашка водосборного бассейна.

Цикл 0 - современность (гл. 0,7-0 м)

Пачка чередующихся линз светлого песка и гумусированной супеси, мощность прослоев от 1 до 5 см. В этой пачке хорошо прослеживается перекрестная слоистость, 
характерная для быстрого отложения песка из перенасыщенного потока. Степень перемешанности и гранулометрический состав прослоев быстро меняются на протяжении дециметров, что типично для склоновых процессов на пашне и пастбищах. Современный гумусовый горизонт мощностью 15 см с зернисто-комковатой структурой развит на этой аллювиально-пролювиальной толще. Дерновая почва сформирована на наносах, отложившихся после обезлесения и сельскохозяйственного освоения прибрежной полосы.

Таким образом, в трехметровом слое отложений, вскрытых береговыми обрывами Суры, прослеживаются следы пяти циклов, отражающих изменения режима поемности. Судя по мощности погребенных гумусовых горизонтов, сформировавшихся в периоды стабилизации поверхности, всего два этапа низкой поемности длились не менее нескольких столетий, отразившись в формировании почв III и II. Культурный слой селища Устье Малой Сарки связан с первым из них (почва III).

II. Стратиграфия разреза балочных отложений у селищ Capa-1 и 2

В балке, разделяющей селища Capa-1 и Сара-2 (рис. 4: С), был вскрыт стратозем, состоящий из современной почвы, залегающей на дневной поверхности, и трех почв, погребенных под овражно-балочными отложениями в результате эпизодов эрозии на водосборном участке. Ниже приведена краткая характеристика циклов осадконакопления и почвообразования, от наиболее древного к наиболее молодому (табл. 2).

\section{Цикл 4}

В основании педолитогенного комплекса залегает серая лесная почва, развитая на лессовидном суглинке $(\mathbf{5 B t})$. По строению профиля погребенная почва соответствует серой лесной почве. Наличие углей в гумусовом горизонте (4Ab(pyr)) указывает на то, что лес был пройден пожаром, а отсутствие следов комлей деревьев, плитчатость, характерная для уплотнения почвенной массы, и ровная верхняя граница гумусового горизонта с перекрывающим наносом - на то, что участок был залужен на момент погребения поверхности. Лес-пожар или выжиг-залужение.

\section{Цикл 3}

Поверхность погребенной почвы перекрыта преобразованным почвообразованием, наносом буровато-средне-серого суглинка $(\mathbf{B A B u})-$ переотложенным в результате склоновых прочессов культурным слоем селища Сара-2. Переотложенный культурный слой переходит по диффузной верхней границе в более светлоокрашенный делювиальный нанос (3АВ), переработанный почвообразованием (предположительно, лесного типа). Верхняя часть наноса преобразована в темноцветный гумусовый горизонт $(\mathbf{3} \boldsymbol{A b})$, маркирующий луговую черноземовидную почву, которая образовалась на обезлесенном участке во время теплой, сухой климатической фазы.

\section{Цикл 2}

Гумусовый горизонт луговой почвы $(3 \boldsymbol{A b})$ переходит по неровной, но четкой границе в более светлоокрашенный слой $(2 A p)$, соответствующий горизонту распашки. Судя по тому, что в погребенном под (2Ap) гумусовом горизонте $(\boldsymbol{B} \boldsymbol{A b})$ многочисленны землероины, которые отсутствуют в вышележащих слоях, и по заметному осветлению общей массы пахотного горизонта по сравнению с погребенным под ним гумусовым горизонтом, между этапом залужения и распашки был перерыв, возможно, сопровождавшийся облесением. Цикл 2, таким образом, отражает распашку примыюающего участка.

\section{Цикл 1}

Поверхность распаханной почвы (2Ap) перекрыта наносом, на котором развит горизонт $(\mathbf{1 A p})$ с характерной для пашни волнистой поверхностью, с амплитудой 5-7 см и длиной волны 19-20 см. На поверхности минеральной почвы накоплена дернина. Старопахотная почва, заброшенная в залежь.

III. Стратиграфическое соотношение пойменных и балочного разрезов

Точная хронологическая корреляция разрезов возможна только на основании радиоуглеродных датировок и анализа макроостатков в сравниваемых слоях, однако стратиграфический анализ позволяет сделать некоторые предварительные выводы.

Как указывалось выше, в пойменных разрезах выделено пять древних и современ- 
Таблица 2. Стратиграфия разреза в балке между селищами Сара-1 и 2 (шурф 1)

[Table 2. Stratigraphic profile for a gully between Sara-1 and 2 settlements (test pit 1)]

\begin{tabular}{|c|c|c|c|}
\hline Цикл & Слой & Мощность & Описание \\
\hline 0 & $O$ & $4-9$ & Дернина \\
\hline \multirow[t]{2}{*}{1} & $1 A p$ & $21-25$ & $\begin{array}{l}\text { Однородно-окрашенный темно-серый легкий суглинок, в нижней } \\
\text { части более светлого тона за счет кремнеземистой присыпки, рыхлый, } \\
\text { с комковато-зернистой структурой (зерна 2-3 мм), нижняя граница } \\
\text { ровная. Поверхность почвы волнистая, с амплитудой 5-7 см и длиной } \\
\text { волны } 19-20 \text { см, характерной для поверхности пашни }\end{array}$ \\
\hline & $1 A B$ & $9-15$ & $\begin{array}{l}\text { Нанос опесчаненного светло-серого суглинка с прослоем песка, } \\
\text { маркирующим линейную почвенную эрозию, в верхней части слоя }\end{array}$ \\
\hline 2 & $2 A p$ & $12-25$ & $\begin{array}{l}\text { Однородно- и светлоокрашенный средне-серый горизонт, опесчанен- } \\
\text { ный средний суглинок с комковато-мелкозернистой (1-2 мм) структу- } \\
\text { рой; по нижней границе слоя, на глубине } 60 \text { см, многочисленны норы } \\
\text { землероев. Верхняя граница с кроющим наносом ровная, заметна по } \\
\text { увеличению опесчаненности }\end{array}$ \\
\hline \multirow[t]{3}{*}{3} & $3 A b$ & $12-15$ & $\begin{array}{l}\text { Темноцветный гумусовый горизонт - коричневато-темно-серый } \\
\text { средний суглинок с зернистой структурой, единичными вкраплениями } \\
\text { угля и сажистыми включениями; окраска неоднородная за счет } \\
\text { землероин-норы опущены споверхности слоя }(\mathrm{d}=6-8 \text { см }) \text { и заполнены } \\
\text { темно-серым гумусированным материалом или мелкопятнистой } \\
\text { смесью гумусированного и негумусированного материалов }\end{array}$ \\
\hline & $3 A B$ & $17-20$ & $\begin{array}{l}\text { Палево-белесо-серый пылеватый суглинок, светлоокрашенный, с еди- } \\
\text { ничными артефактами, перенесенными землероями из нижележащего } \\
\text { слоя - делювиальный нанос, переработанный почвообразованием }\end{array}$ \\
\hline & $3 A B u$ & $30-50$ & $\begin{array}{l}\text { Нанос буровато-средне-серого суглинка, преобразованный почвооб- } \\
\text { разованием - рыхлый, с зернистой структурой, с пятнами землероин } \\
(\mathrm{d}<10 \text { см) и с многочисленными включениями углей и керамики }\end{array}$ \\
\hline \multirow[t]{2}{*}{4} & $4 A b(p y r)$ & $7-10$ & $\begin{array}{l}\text { Темно-серый гумусовый горизонт - плотный, бесструктурный } \\
\text { пылеватый суглинок с включениями углей (<1 см), достаточно } \\
\text { равномерно распределенных по слою, верхние 5-7 см гумусового } \\
\text { горизонта темнее и плотнее нижележащего, структура плитчатая; } \\
\text { переходит в нижележащий слой по ровной, диффузной границе }\end{array}$ \\
\hline & $4 A E$ & $6-10$ & $\begin{array}{l}\text { Белесо-серо-палевый пылеватый суглинок, бесструктурный, переход в } \\
\text { нижележащий горизонт постепенный }\end{array}$ \\
\hline - & $5 B t$ & - & $\begin{array}{l}\text { Средний суглинок бурого цвета с глинистыми кутанами по поверх- } \\
\text { ностям почвенных отдельностей, с узкими вертикальными заходами } \\
\text { гумусированного материала по трещинам на глубине до } 18 \text { см от ниж- } \\
\text { ней границы гумусового горизонта. Граница с вышележащим наносом } \\
\text { ровная, четкая по цвету и плотности }\end{array}$ \\
\hline
\end{tabular}

ный этапы осадконакопления. В отличие от них, в балке читаются всего два этапа.

Первому из них предшествовала фаза лесного почвообразования под широколиственным лесом, в результате которого была сформирована серая лесная почва (цикл 4). В пойме следы аналогичной лесной почвы отмечены только в IV цикле, что позволяет синхронизировать его с циклом 4 в балке. Первый этап осадконакопления, прослеженный в цикле 3 , был связан с пожаром (выжигом?) и расчисткой лесного участка: в этот период поверхность серой лесной почвы в балке залужается, утаптывается и погребается под переотложенным культурным слоем селища. Цикл 3 шурфа 1 , таким образом, может быть синхронизирован с III циклом в пойменных разрезах, на что указывает также близость археологических находок (рис. 6).

Этап эрозии на водосборе балки сменился залужением участка и формированием лугово-черноземной почвы, т. е. участок оставался безлесным на фоне сухого и жаркого климата. Темноцветные почвы лугово-черноземного типа формировались в пойме в течение цикла II, во время теплой и засушливой климатической фазы, вероятно датирующейся периодом Малого климатического оптимума (VIII-XIII вв.). 
Второй этап осадконакопления в балке связан с повторной распашкой участка (цикл 2); большая мощность пахотного горизонта, близкая к современной, говорит в пользу его относительной молодости предположительно, распашка произошла в Новое время. Исходя лишь из стратиграфического анализа, трудно заключить, какие события происходили между формированием темноцветной луговой почвы и распашкой участка — в частности, разделял ли их этап облесения. В пойме второму этапу осадконакопления соответствуют современная и наиболее молодая погребенная $(\boldsymbol{I A b})$ почвы, разделенные аллювиальными наносами.

\section{Заключение}

Проведенное исследование пойменных и балочных отложений р. Суры выявило пять этапов низкой поемности, из которых четыре сопровождались формированием автоморфных почв. Описанное местонахождение с более дробным, чем региональный, архивом палеогидрологических условий представляет возможности для более подробной реконструкции условий обитания человеческих коллективов. Каждый из описанных этапов отражает изменение природно-климатических условий в регионе, в первую очередь - динамику поверхностного стока, связанную с уровнем осадков и характером растительного покрова в пределах водосборного бассейна.

В основании изученных разрезов залегают отложения пойменного озера на месте современного русла. Их верхняя часть была преобразована в гидроморфную почву $(\mathrm{V})$ при понижении водности и дренировании озера. Судя по времени заболачивания других пойменных озер в Татарстане, она могла сформироваться около 7,2-7,1 т. л. н. [Бакин и др. 2011; Бутаков и др. 2000].

В диапазоне от 7 до 5 т. л. н., во время средне-голоценового климатического оптимума, в поймах рек Восточноевропейской равнины формировались темноцветные погребенные почвы, зачастую вмещающие артефакты [Александровский, Александровская 2005]. Темноцветные «атлантические» почвы были описаны и в Среднем Поволжье [Галимова и др. 2016; Курбанова 1991]. На изученном участке следы этой почвы отсутствовали, что может говорить об изменении положении русла Суры при уве- личении водности в начале суббореала ( 54,7 т. л. н.) - по-видимому, этим же временем датируется нижняя граница пойменных отложений в наших разрезах. В этот период происходит увеличение стока р. Суры, смещение положения ее русла и формирование поймы на изучаемом участке. К концу цикла пойма зарастает лесом, под которым формируются автоморфные серые лесные почвы (почва IV), которые оглеиваются при повышении водности в начале следующего цикла. Этому периоду повышенной поемности соответствуют единичные находки раннего железного века - ананьинского (VIII-IV вв. до н. э.), а затем - сендимиркинско-таутовского (II-III вв. н. э.) облика. Отсутствие массовых находок керамического материала и селитебных слоев, соответствующих найденным артефактам, говорит об отсутствии поселений в пойме в этот период, что могло быть обусловлено периодическими паводками. Наблюдаемая картина соответствует имеющимся сведениям о системе расселения в целом по региону: так, для ранних древнемордовских групп характерно освоение участков высоких террас и коренных берегов рек [Мясников 2013].

Продолжительный этап низкой поемности и залесенности поймы. В этот период происходит хозяйственное освоение поймы - антропогенное сведение (выжигание) лесов и последующее залужение поверхности (почва III). Этап соответствует времени существования селища Устье Малой Сарки (IV-V вв. н. э.), а также других поселений III-V вв. в его округе. Освоение пойм в это время происходит и в других регионах Среднего Поволжья: в бассейнах рр. Большой Черемшан (Новокиреметское II селише [Истомин и др. 2017], Курманаевское IV селище [Халимуллина 2020]), Свияги (Карлинское III и $I V$ селища [Вязов, Семыкин 2016: 77]) и др.

Погребенные почвы IV и III периодов - серые лесные, что свидетельствует о господстве в поймах широколиственных лесов. Длительный период низкой поемности, сопровождавшийся формированием автоморфных лесных (дерново-подзолистых и серых лесных) погребенных почв и появлением поселений раннего железного века в поймах, был описан для многих рек Восточно-Европейской равнины [Alexandrovsky et al. 2018; Сычева 2019]. Так, в поймах Сред- 
него Поволжья и Прикамья были описаны погребенные серые лесные почвы, вмещающие находки III-V вв. н. э. [Мозжерин, Курбанова 2004; Галимова и др. 2016; Курбанова 1991].

Окончание III - начало II цикла ознаменовалось быстрым, резким увеличением стока и интенсификацией паводков. Этому этапу соответствует время существования именьковской культуры развитого этапа (2 половина V-VI вв. н. э.), носители которой осваивали высокие террасы [Вязов, Семыкин 2016: 86].

За этим последовал этап низкой поемности и остепнения/залужения пойменных ландшафтов (почва II), который может быть отнесен к эпохе Малого Климатического Оптимума (МКО, VIII-XIII вв.) на основании «степного» типа гумусонакопления и распространения землероев [Пономаренко и др. 2015]. С этого же периода во всех погребенных гумусовых горизонтах поймы Суры отмечается копрогенная структура, связанная с деятельностью червей. Автоморфные почвы эпохи МКО описаны в бассейнах Оки, Москвы, Днепра и Верхнего Дона и рассматриваются как региональные маркеры низкой поемности [Сычева 2011; Сычева 2019]. Специальные исследования, посвященные освоению пойм в эпоху средневековья на территории Среднего Поволжья, отсутствуют. Вместе с тем исследователями отмечается топографическая приуроченность поселений конца IX - начала XI вв. к пойменным ландшафтам [Руденко 2007: 15; Руденко 2012: 73].

C начала суббореала до МКО (циклы IV, III и II) периоды стабилизации поверхности между паводками были достаточно продолжительными для того, чтобы исходная слоистость аллювиальных наносов большей частью стерлась биотурбацией. Ситуация радикально изменилась на последующем этапе: паводки становятся частыми и интенсивными, происходит отступание берега за счет эрозии, формируются конусы выноса аллювиально-пролювиальных отложений и откладывается слоистый аллювий-«наилок». В этот период происходит распашка приречных террас и водоразделов. Из-за высоких интенсивных паводков, характерных для обезлесенных водосборных бассейнов, мощность и количество уцелевших поверхностных образований (молодых почв) варьирует даже в пределах нескольких десятков метров. Высокие и продолжительные паводки, связанные с многоснежными зимами и масштабной распашкой земель, на территории Русской равнины были характерны для Малого Ледникового Периода (XIV-XIX вв.) [Сычева 2011]. В Среднем Поволжье наилок начал накапливаться около 700 лет назад [Бутаков и др. 2000], но начало этого процесса в Посурье еще не датировано. Наконец, этап формирования старопахотной почвы I четко маркирует еще один период низкой поемности, который, вероятно, относится к концу позднего средневековья - началу Нового времени.

Для реконструкции динамики хозяйственного освоения Посурья в I тыс. н. э. принципиально важное значение имеет третий из выделенных периодов (цикл III). По имеющимся археологическим и радиоуглеродным датировкам ${ }^{1}$, этот период в Посурье охватывает всю 2 четверть I тыс. н. э. Важно отметить, что динамика обводненности пойм, судя по всему, носила асинхронный характер, и фазы низкой поемности имели различную продолжительность, несмотря на связность обуславливавших их климатических колебаний на территории Восточной Европы [Benito et al. 2015; Panin, Matlakhova 2015]. Так, в пойме Москвы-реки возраст почвы раннего железного века (почва 2 по Александровскому) оценивается в рамках 2100-700 л. н. [Alexandrovsky et al. 2018], в пойме средней Оки 2800-1100 л. н. [Воробьев 2018], в пойме Днепра 2300-900 л. н. [Panin et al. 2014]. Не исключено, что именно отмечаемая асинхронность инундации пойм являлась одним из факторов миграционных процессов. Так, доступность пойм средневолжских рек для хозяйственного освоения и даже заселения в этот период могла стать одним из факторов, обусловивших возможность расселения на этих территориях носителей киевской культуры, для которых именно пойменные ландшафты являлись привычной средой обитания в исходных регионах их миграций.

Проведенные исследования показали высокую информативность пойменных отложений долины Суры в целом и изучен-

1 Радиоуглеродные датировки были получены по растительным макроостаткам и будут приведены во второй части настоящего исследования. 
ного участка в частности для реконструкции динамики климатических изменений и этапов антропогенного освоения региона в древности и средневековье и заложили

\section{Литература}

Александровский, Александровская 2005 Александровский А. Л., Александровская Е. И. Эволюция почв и географическая среда. М.: Наука, 2005. 221 с.

Александровский, Гласко 2014 - Александровский А. Л., Гласко М. П. Взаимодействие аллювиальных и почвообразовательных процессов на разных этапах формирования пойм равнинных рек в голоцене (на примере рек центральной части Восточно-Европейской равнины) // Геоморфология. 2014. № 4. C. 3-17.

Воробьев 2018 - Воробьев А. Ю. Типы и особенности проявления морфолитогенеза в пойменной части долины Оки в ее среднем течении: дисс. ... канд. геогр. наук. М., 2018. $238 \mathrm{c}$.

Бакин и др. 2011 - Бакин О. В., Панова Н. К., Антипина Т. Г. История Пестречинского торфяника (материалы по истории голоцена Татарстана) // Археология и естественные науки Татарстана. Кн. 4. Казань: ООО «Фолиант», 2011. С. 202-216.

Бутаков и др. 2000 - Бутаков Г. П., Курбанова С. Г., Панин А. В., Перевошиков А. А., Серебренникова И. А. Формирование антропогенно-обусловленного наилка на поймах рек Русской равнины // Эрозионные и русловые процессы. Вып. 3. М.: МГУ, 2000. С. 78-92.

Вязов и др. 2016 - Вязов Л. А., Гришаков В. В., Мясников Н. C. Особенности керамических комплексов памятников Среднего Посурья эпохи Великого переселения народов // Вояджер: мир и человек: теоретический и научно-методический журнал. 2016. № 6 . C. $66-111$.

Вязов и др. $2020-$ - Вязов Л. А., Михайлов Е. П., Макарова Е. М., Мясникова А. Б., Мясников Н. С., Петрова Д. А., Салова Ю. А., Силанов Р. А. Исследования памятников Среднего и Нижнего Посурья в рамках работы международной археологической экспедиции в 2015-2019 гг. // Археология Евразийских степей. 2020. № 3. С. 354-373.

Вязов, Семыкин 2016 - Вязов Л. A., Ceмbкин Ю. А. Городище и селище Новая Беденьга: эпоха Великого переселения народов в Ульяновском Предволжье. Серия «Археология Симбирского-Ульяновского Поволжья». основу для реконструкции динамики экосистем и истории природопользования, которая будет представлена во второй части статьи.

Вып. 1. Ульяновск: НИИ истории и культуры им. Н. М. Карамзина, 2016. 227 с.

Вязов, Сташенков 2013 - Вязов Л. А., Сташенков Д. А. Культурно-хронологические группы населения Самарского и Ульяновского Поволжья в эпоху Великого переселения народов // Историко-культурное наследие ресурс формирования социально-исторической памяти гражданского общества. (XIV Бадеровские чтения). Ижевск: Удмуртск. ун-т, 2013. С. 49-56.

Галимова и др. 2016 - Галимова М. Ш., Хисяметдинова А. А., Аськеев И. В., Шаймуратова (Галимова) Д. Н., Аськеев О. В. Природное окружение и хозяйственная деятельность обитателей стоянки Пестречинская 2 на р. Мёша // Поволжская археология. 2016. № 3 (17). С. 168-193.

Истомин и др. 2017 - Истомин К. Э., Вязов Л. А., Салова Ю. А. Исследования Новокиреметского II селища // Археологические открытия. 2015. М.: Наука, 2017. С. 324-326.

Кренке 2019 - Кренке Н. А. Идея семинара «Археология поймы: рельеф, палеосреда, история заселения» // Археология поймы: рельеф, палеосреда, история заселения. Тезисы научного семинара (г. Москва, 23 апреля 2019 г.) / под ред. А. Л. Александровского, Н. А. Кренке. М.: КДУ, Университетская книга, 2019. С. 8-9.

Курбанова 1991 - Курбанова С. Г. Палеогеографическое значение погребённых почв пойм малых рек бассейнов Вятки и Средней Волги // Физико-географические основы развития и размещения производительных сил Нечернозёмного Урала. Пермь: Изд-во ПГУ, 1991. С. 118-122.

Мозжерин, Курбанова 2004 - Мозжерин В. И., Курбанова С. Г. Деятельность человека и эрозионно-русловые системы Среднего Поволжья. Казань: АртДизайн, 2004. 128 с.

Мясников 2014 - Мясников Н. С. Новые находки ананьинского времени с территории Чувашии // Ананьинский мир: истоки, развитие, связи, исторические судьбы. Археология евразийских степей. Вып. 20. Казань: Отечество, 2014. С. 276-280.

Мясников 2013 - Мясников Н. С. Этнокультурные процессы в Чувашском Поволжье в I-VIII вв. н. э. в свете археологических дан- 
ных. Доклад на научной сессии Чувашского государственного института гуманитарных наук по итогам работы за 2013 год. Чебоксары: ЧГИГН, 2013. 72 с.

Пономаренко и др. 2015 - Пономаренко Е. В., Пономаренко Д. С., Сташенков Д. А., Кочкина А. Ф. Подходы к реконструкции динамики заселения территории по почвенным признакам // Поволжская археология. 2015. № 1 (11). С. 126-160.

Руденко 2007 - Руденко К. А. Волжская Булгария в XI - начале XIII в.: поселения и материальная культура. Казань: Школа, 2007. $244 \mathrm{c}$.

Руденко 2012 - Руденко К. А. Возникновение городов в Волжской Булгарии и булгарской области Золотой Орды (по данным археологии) // Поволжская археология. 2012. № 1 (1). С. 68-77.

Ситдиков и др. 2016 - Ситдиков А. Г., Вязов Л. А., Пономаренко Е. В., Родинкова В. Е. Международный научно-практический семинар по применению палеоэкологических методов в археологии (Болгар, 9-19 августа 2016 г.) // Поволжская археология. 2016. № 3 (17). С. 251-255.

Сташенков 2005 - Сташенков Д. А. Оседлое население Самарского лесостепного Поволжья в I-V вв. н. э. М.: ИА РАН, СОИКМ им. П. В. Алабина, 2005. 150 с.

Сычева 2011 - Сычева C. А. Малый климатический оптимум голоцена и малый ледниковый период в памяти почв и отложений пойм рек русской равнины // Известия Российской Академии наук. Серия географическая. 2011. № 1. С. 79-93.

Сычева 2019 - Сычева С. А. Палеопочвенные и археологические свидетельства ритмичного развития пойм рек в голоцене // Археология поймы: рельеф, палеосреда, история заселения. Тезисы научного семинара (г. Москва, 23 апреля 2019 г.) / под ред. А. Л. Александровского, Н. А. Кренке. М.: КДУ, Университетская книга, 2019. С. 83-88.

Халимуллина 2020 - Халимуллина Л. Р. О культурной принадлежности памятников эпохи ВПН в бассейне р. Большой Черемшан. К постановке проблемы // LII Урало-Поволжская археологическая конференция студентов и молодых учёных (УПАСК). Мат-лы Bсеросс. науч.-практич. конф. студентов, аспирантов и молодых ученых. Пермь: ПГНИУ, 2020. С. 217-220.

Alexandrovsky et al. 2018 - Alexandrovsky A., Ershova E., Ponomarenko E., Krenke N., Skripkin V. Floodplain Paleosols of Moskva
River Basin: Chronology and Paleoenvironment // Radiocarbon. 2018. 60 (4). Pp. 1169-1184.

Benito et al. 2015 - Benito G., Macklin M. G., Panin A. et al. Recurring flood distribution patterns related to short-term Holocene climatic variability. Scientific Reports. 2015. Vol. 5. Report no. 16398(1)

IUSS Working Group WRB. 2015. World Reference Base for Soil Resources 2014, update 2015 International soil classification system for naming soils and creating legends for soil maps. World Soil Resources Reports No. 106. FAO, Rome.

Kaal et al. 2011 - Kaal J., Carrion Marco Y., Asouti E. et al. Long-term deforestation in NW Spain: linking the Holocene fire history to vegetation change and human activities // Quaternary Science Reviews. 2011. Vol. 30. No. 1-2. Pp. 161-175.

Panin et al. 2014 - Panin A. V., Adamiec G., Arslanov K. A., Bronnikova M. A., Filippov V. V., Sheremetskaya E. D. Absolute chronology of fluvial events in the Upper Dnieper river system and its palaeogeographic implications // Geochronometria. 2014. No. 41 (3). Pp. 278293.

Panin, Matlakhova 2015 - Panin A., Matlakhova E. Fluvial chronology in the East European Plain over the last $20 \mathrm{ka}$ and its palaeohydrological implications // Catena. 2015. No. 130. Pp. 4661.

Ponomarenko et al. 2020 - Ponomarenko E., Ershova E., Ponomarenko D. S., Stashenkov D. A., Kochkina A. F. Tracing land use history using a combination of soil charcoal and soil pollen analysis: An example from colluvial deposits of the Middle Volga Region // Journal of Archaeological Science: Reports. 2020. Vol. 31. Report no. 102269.

Scherer et al. 2021 - Scherer S., Höpfer B., Deckers $K$. et al. Middle Bronze Age land use practices in the north-western Alpine foreland - A multi-proxy study of colluvial deposits, archaeological features and peat bogs. EGU General Assembly 2021, online, 19-30 Apr. 2021, EGU21-15578.

Vyazov et al. 2019 - Vyazov L. A., Ershova E. G., Ponomarenko E. V., Gajewski K., Blinnikov M. S., Sitdikov A. G. Demographic changes, trade routes, and the formation of anthropogenic landscapes in the Middle Volga Region in the past 2500 years // SocioEnvironmental Dynamics along the Historical Silk Road / ed. by Liang Emlyn Yang, HansRudolf Bork, Xiuqi Fang, Steffen Mischke. Springer International Publishing, 2019. Pp. 425-465. 


\section{References}

Aleksandrovsky A. L., Aleksandrovskaya E. I. Soil Evolution and Geographic Environment. Moscow: Nauka, 2005. 221 p. (In Russ.)

Aleksandrovsky A. L., Glasko M. P. Interaction of alluvial and soil formation processes at different stages of the flood plains development during the Holocene (The rivers of the central part of the East European Plain as an example). Geomorfologiya. 2014. No. 4. Pp. 3-17. (In Russ.)

Alexandrovsky A., Ershova E., Ponomarenko E., Krenke N., Skripkin V. Floodplain paleosols of Moskva River Basin: Chronology and paleoenvironment. Radiocarbon. 2018. No. 60 (4). Pp. 1169-1184. (In Eng.)

Bakin O. V., Panova N. K., Antipina T. G. History of Pestrechinsky peat bog: Holocene in Tatarstan. In: Archaeology and Natural Sciences of Tatarstan. Vol. 4. Kazan: Foliant; Märcani Institute of History, 2011. Pp. 202-216. (In Russ.)

Benito G., Macklin M. G., Panin A. et al. Recurring flood distribution patterns related to shortterm Holocene climatic variability. Scientific Reports. 2015. Vol. 5. Report no. 16398(1) (In Eng.)

Butakov G. P., Kurbanova S. G., Panin A. V., Perevoshchikov A. A., Serebrennikova I. A. Rivers of the Russian Plain: Formation of anthropogenic slit deposit. In: Erosional and Channel Processes. Vol. 3. Moscow: Moscow State University, 2000. Pp. 78-92. (In Russ.)

Galimova M. Sh. et al. Environment and economic activity of the Pestretsy 2 site inhabitants on the Mesha River. The Volga River Region Archaeology. 2016. No. 3 (17). Pp. 168-193. (In Russ.)

Istomin K. E., Vyazov L. A., Salova Yu. A. Exploring settlement II at Novaya Kiremet. In: Archaeological Discoveries of 2015. Moscow: Nauka, 2017. Pp. 324-326. (In Russ.)

IUSS Working Group WRB. 2015. World Reference Base for Soil Resources 2014, update 2015 International soil classification system for naming soils and creating legends for soil maps. World Soil Resources Reports No. 106. FAO, Rome. (In Eng.)

Kaal J. et al. Long-term deforestation in NW Spain: Linking the Holocene fire history to vegetation change and human activities. Quaternary Science Reviews. 2011. Vol. 30. No. 1-2. Pp. 161175. (In Eng.)

Khalimullina L. R. The Migration Period in the Bolshoy Cheremshan River Basin: Cultural features revisited. In: The Fifty Second Ural-Volga Archaeological Conference of Students and Young Scientists (UPASK). Conference pro- ceedings. Perm: Perm State University, 2020. Pp. 217-220. (In Russ.)

Krenke N. A. Archaeology of floodplains: Terrain, paleoenvironment, population history. Seminar concept. In: Aleksandrovsky A. L., Krenke N. A. (eds.) Archaeology of Floodplains: Terrain, Paleoenvironment, Population History. Seminar theses (Moscow; April 23, 2019). Institute of Archeology (RAS). Moscow: KDU, Universitetskaya Kniga, 2019. Pp. 8-9. (In Russ.)

Kurbanova S. G. The Vyatka and Middle Volga basins: Paleogeographic significance of buried soils within minor river floodplains. In: Productive Forces of the Nonchernozem Urals. Physical and Geographical Essentials of Development and Distribution. Perm: Perm State University, 1991. Pp. 118-122. (In Russ.)

Mozzherin V. I., Kurbanova S. G. The Middle Volga: Anthropogenic Activity and Erosional-Chanel Systems. Kazan: ArtDizayn, 2004. 128 p. (In Russ.)

Myasnikov N. S. Ethnocultural Processes in the Chuvash Volga Area, $1^{\text {st }}$ to $8^{\text {th }}$ Centuries AD: An Archaeological Perspective. Annual report (2013). Cheboksary: Chuvash state Institute of Humanities, 2013. 72 p. (In Russ.)

Myasnikov N. S. New findings of the Ananyino era from Chuvashia. In: The World of Ananyino Culture. Origins, Development, Ties, Historical Destinies. Archaeology of Eurasian Steppes. Vol.20. Kazan: Otechestvo, 2014. Pp. 276-280. (In Russ.)

Panin A., Matlakhova E. Fluvial chronology in the East European Plain over the last $20 \mathrm{ka}$ and its palaeohydrological implications. Catena. 2015. No. 130. Pp. 46-61. (In Eng.)

Panin A. V. et al. Absolute chronology of fluvial events in the Upper Dnieper river system and its palaeogeographic implications. Geochronometria. 2014. No. 41 (3). Pp. 278-293. (In Eng.)

Ponomarenko E. V. et al. Approaches to the reconstruction of dynamic of the territory occupation according to the soil signs. The Volga River Region Archaeology. 2015. No. 1 (11). Pp. 126160. (In Russ.)

Ponomarenko E. et al. Tracing land use history using a combination of soil charcoal and soil pollen analysis: An example from colluvial deposits of the Middle Volga Region. Journal of Archaeological Science: Reports. 2020. Vol. 31. Report no. 102269. (In Eng.)

Rudenko K. A. Occurrence of cities Volga Bulgaria and Bulgars areas of the Gold Horde (according to archaeology). The Volga River Region Archaeology. 2012. No. 1 (1). Pp. 68-77. (In Russ.) 
Rudenko K. A. Volga Bulgaria, $11^{\text {th }}$ to Early $13^{\text {th }}$ Centuries: Settlements and Material Culture. Kazan: Shkola, 2007. ... p. (In Russ.)

Scherer, S., Höpfer, B., Deckers, K. et al. Middle Bronze Age land use practices in the north-western Alpine foreland - A multi-proxy study of colluvial deposits, archaeological features and peat bogs. EGU General Assembly 2021, online, 19-30 Apr. 2021, EGU21-15578. (In Eng.)

Sitdikov A. G., Vyazov L. A., Ponomarenko E. V., Rodinkova V. E. International theoretical and practical workshop on application of paleo-ecological methods in archaeology (Bolgar, 9-19 August 2016). The Volga River Region Archaeology. 2016. No. 3 (17). Pp. 251-255. (In Russ.)

Stashenkov D. A. Samara Forest-Steppe of the Volga Region, $1^{\text {st }}-5^{\text {th }}$ Centuries CE: Sedentary Population Reviewed. Moscow: Institute of Archaeology (RAS), Alabin Samara Oblast Museum of Local History and Lore, 2005. 150 p. (In Russ.)

Sycheva S.A. Little climatic Holocene optimum and the Little Ice Age in the memory of soils and deposits of riversэ floodplains of the Russian plains. Izvestiya Rossiiskoi Akademii Nauk. Seriya Geograficheskaya. 2011. No. 1. Pp. 7993. (In Russ.)

Sycheva S. A. Rhythmic development of floodplains in the Holocene: Paleosoil and archaeological evidence. In: Aleksandrovsky A. L., Krenke N. A. (eds.) Archaeology of Floodplains: Terrain, Paleoenvironment, Population History. Seminar theses (Moscow; April 23, 2019). Institute of Archeology (RAS). Moscow: KDU, Universitetskaya Kniga, 2019. Pp. 83-88. (In Russ.)

Vorobyov A. Yu. Morpholithogenesis in the Floodplain Part of the Oka River Valley (Middle
Reaches): Types and Features. Cand. Sc. (geography) thesis. Moscow, 2018. 234 p. (In Russ.)

Vyazov L. A. et al. Studies of the archaeological sites in the Middle and Lower Sura Region as a part of the work of the international archaeological expedition in 2015-2019. Arkheologiia Evraziiskikh Stepei (Archaeology of the Eurasian Steppes). 2020. No. 3. Pp. 354-373. (In Russ.)

Vyazov L. A., Ershova E. G., Ponomarenko E. V., Gajewski K., Blinnikov M. S., Sitdikov A. G. Demographic changes, trade routes, and the formation of anthropogenic landscapes in the Middle Volga Region in the past 2500 years. In: Yang L. E. et al. (eds.) Socio-Environmental Dynamics along the Historical Silk Road. Springer International Publishing, 2019. Pp. 425-465. (In Eng.)

Vyazov L. A., Grishakov V. V., Myasnikov N. S. Features of ceramic complexes of the Great Migration period monuments in of the Middle Sura Region. Voyadzher: mir i chelovek. 2016. No. 6. Pp. 66-111. (In Russ.)

Vyazov L. A., Semykin Yu. A. Hillfort and Settlement of Novaya Bedenga: The Migration Period in Ulyanovsk Area of the Volga Region. Series 'Volga Region: Archaeology of Simbirsk (Ulyanovsk)'. Vol. 1. Ulyanovsk: Karamzin Institute of History and Culture, 2016. 227 p. (In Russ.)

Vyazov L. A., Stashenkov D. A. Samara and Ulyanovsk areas of the Volga Region during the Migration Period: Cultural and chronological population groups. In: Historical and Cultural Heritage as a Resource to Shape Sociohistorical Memory of Civil Society. The Fourteenth Bader Readings. Izhevsk: Udmurtiya Univ. Press, 2013. Pp. 49-56. (In Russ.) 